Georgetown University Law Center

Scholarship @ GEORGETOWN LAW

2001

\title{
Collusion and Collective Action in the Patent System: A Proposal for Patent Bounties
}

John R. Thomas

Georgetown University Law Center, jrt6@law.georgetown.edu

This paper can be downloaded free of charge from:

https://scholarship.law.georgetown.edu/facpub/306

2001 U. III. L. Rev. 305-353 (2001)

This open-access article is brought to you by the Georgetown Law Library. Posted with permission of the author.

Follow this and additional works at: https://scholarship.law.georgetown.edu/facpub

Part of the Courts Commons, and the Intellectual Property Law Commons 


\title{
GEORGETOWN LAW Faculty Publications
}

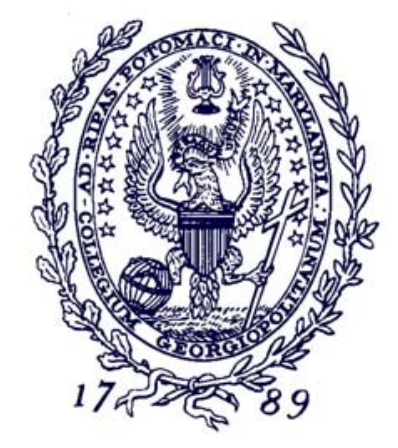

March 2010

\section{Collusion and Collective Action in the Patent System: A Proposal for Patent Bounties}

\author{
2001 U. Ill. L. Rev. 305-353 (2001) \\ John R. Thomas \\ Professor of Law \\ Georgetown University Law Center \\ jrt6@law.georgetown.edu
}

This paper can be downloaded without charge from:

Scholarly Commons: http://scholarship.law.georgetown.edu/facpub/306/ 


\title{
COLLUSION AND COLLECTIVE ACTION IN THE PATENT SYSTEM: A PROPOSAL FOR PATENT BOUNTIES
}

John R. Thomas*

\begin{abstract}
Persistent commentary contends that the Patent Office is issuing patents that appropriate public domain concepts at an alarming frequency. Complaints of low patent quality enjoy growing resonance with regard to business methods, computer software, and other inventions for which patents were not traditionally sought. In this article, Professor Jay Thomas explains how the judiciary's lenient view of patentable subject matter and utility standards, along with miserly congressional funding policies, have rendered the Patent Office an increasingly porous agency.

Professor Thomas next reviews existing proposals for improving patent quality, including the conventional wisdom that adoption of an opposition system will contribute meaningfully to the solution of our patent quality problem. Exploring the political economy of patent challenges, Professor Thomas reasons that oppositions do little to solve collective action problems, the possibility of collusion between the prior art holder and patentee, and the existence of the first inventor defense. Professor Thomas instead proposes that the Patent Office recruit members of the public to act as private patent examiners. By awarding prior art informants with a bounty assessed against applicants, the Patent Office can restore order to the patent system and reduce its social costs.
\end{abstract}

\section{INTRODUCTION}

The patent system has reaped a dubious harvest from policies of the past decade. An unbridled judicial vision of patentable subject matter has enlarged the scope of appropriable inventions from traditional tech-

* Associate Professor of Law, George Washington University.

The author wishes to thaink Marty Adelman, Gregory Aharonian, Ian Ayres, Julie Cohen, Rochelle Dreyfuss, Mark Janis, Jay Kesan, Mark Lemley, Gideon Parchomovsky, Jerry Reichman, and Rodger Schechter for their helpful remarks. I also benefited greatly from interactions with participants at the University of Illinois College of Law and Institute of Government and Public Affairs symposium on: Intellectual Property Challenges in the Next Century, as well as from discussions following workshop presentations at the Cornell Law School and Georgetown University Law Center. 
nologies to virtually any human endeavor. ${ }^{1}$ The coupling of this ambitious sense of patent eligibility with congressional policies that stripped sorely needed resources from the Patent Office has once again focused withering criticism upon the regime of patents. ${ }^{2}$ Observers have directed attention to a host of improvidently granted patents, ${ }^{3}$ passionately urged that patent attorneys are "stealing our future," and generally declared the patent system to be in a state of crisis. ${ }^{5}$ This chorus of complaints enjoys an increasing resonance with regard to business methods, computer software, and other inventions that until recently were believed without the patent system. ${ }^{6}$

This article identifies the problems of a patent system in transition and proposes specific reforms. It is written with some sense of urgency. Experience teaches us that the patent system is prone to abuse by the monopolist and speculator, and that the inevitable public reaction is one of cynicism and hostility towards patents. Intemperate patenting of software and business methods appears well on its way to breeding further distrust. If the patent system cannot achieve greater accessibility and accountability to the unfamiliar disciplines now under its wing, many of the spectacular reforms it has achieved over the past twenty years may go for naught. ${ }^{7}$

This article begins in part II by briefly explaining core economic and legal principles of the patent law. In part III, I consider contentions that the Patent Office is issuing patents of poor quality in disciplines unfamiliar to it. This part reviews the unfortunate combination of events that allowed Congress to deprive the Patent Office of funding while the Federal Circuit vastly expanded the possibilities for patentable subject matter. The stakes are high, part III concludes, because many inventions that have only recently been judged as patentable concern information goods. Such postindustrial products frequently exhibit network effects and promote lock-in, and their associated patents need not be judged as valid for very long to have significant market effects.

\footnotetext{
2. More properly the United States Patent and Trademark Office. See 35 U.S.C. $\$ 1$ (1994).

3. E.g., Byron L. Winn, Readers Say, ForBES, May 31, 1999, at 18 (ridiculing the granting of a patent for the Dutch auction); Legal Resources and Tools for Surviving the Patenting Frenzy of the Internet, Bioinformatics, and Electronic Commerce: Archive of Bad Software/Internet Patents, at http://www.bustpatents.com (last visited January 16, 2001) (listing invalidated patents) (on file with the University of Illinois Law Review).

4. Jesse Berst, How Patent Attorneys Are Stealing Our Future, ZDNET (Jan. 18, 2000), at http://www.zdnet.com/anchordesk/story/story..4364.html (on file with the University of Illinois Law Review).

5. See Robert P. Merges, As Many as Six Impossible Patents Before Breakfast: Property Rights for Business Concepts and Patent System Reform, 14 BERKELEY TECH. L.J. 577,591 (1999).

6. See John R. Thomas, The Post-Industrial Patent System, 10 Fordham InTell. Prop. Media \& ENT. L.J. 3, 10-17 (1999).

7. See Rochelle Cooper Dreyfuss, The Federal Circuit: A Case Study in Specialized Courts, 64 N.Y.U. L. REV. 1, 24-25 (1989).
}

1. See John R. Thomas, The Patenting of the Liberal Professions, 40 B.C. L. REV. 1139, 1139 (1999). 
In part IV, I review recent patent reform proposals directed towards patent quality problems. This article discovers that the academic community has supported the adoption of so-called opposition proceedings with extraordinary vigor and unanimity. ${ }^{8}$ Typically styled after proceedings conducted in the European Patent Office, oppositions allow interested members of the public to contest the merits of a pending patent application or issued patent at the Patent Office. ${ }^{9}$ If only we can make oppositions inexpensive and efficient enough to supplant notoriously resource-intensive patent litigation, we are made to understand, stakeholders will flock to the Patent Office with pertinent patent-defeating references. ${ }^{10}$ This conventional wisdom has made its way to Congress, as evidenced by the October 3, 2000, introduction of H.R. 5364, titled the Business Method Patent Improvement Act of 2000. ${ }^{11}$ If enacted, introduction of H.R. 5364 would establish opposition procedures for patent applications claiming business method inventions. ${ }^{12}$

This article urges further reflection upon the utility of oppositions in solving patent quality problems. Opposition proposals may not have sufficiently accounted for private incentives that are misaligned with the public interest in defeating invalid patents. Put another way, oppositions present considerable externalities. Not only are opposition regimes ripe with collective action and free rider problems, they do not account for the possibility of collusion between the patentee and holder of patentdefeating prior art. Recent legislative developments will likely exaggerate these tendencies within the area of business methods. By creating a defense for earlier inventors of business methods that were later patented by another, ${ }^{13}$ Congress may have provided those individuals best able to defeat an invalid patent with a more attractive alternative for escaping infringement liability.

Part $\mathrm{V}$ of this article suggests that we assume a different tack. I propose that the Patent Office award cash prizes to informants who timely disclose patent-defeating references. Such a regime will establish a class of private patent examiners who are encouraged to research and disclose patent-defeating references. If patent applicants themselves are assessed this bounty, then the Patent Office will also encourage patent applicants to determine the pertinent prior art and draft patent claims of

8. E.g., Rochelle Cooper Dreyfuss, Dethroning Lear: Licensee Estoppel and the Incentive to Innovate, 72 VA. L. REV. 677, 754 n.277 (1986); Mark D. Janis, Rethinking Reexamination: Toward a Viable Administrative Revocation System for U.S. Patent Law, 11 HARV. J.L. \& TECH. 1 (1997); Merges, supra note 5, at 611-12; Craig A. Nard, Certainty, Fence Building, and the Useful Arts, 74 IND. L.J. 759 (1999); J.H. Reichman, From Free Riders to Fair Followers: Global Competition Under the TRIPS Agreement, 29 N.Y.U. J. INT'L L. \& POL. 11, 31 (1997).

9. See infra notes 179-92 and accompanying text.

10. E.g., Merges, supra note 5, at 615.

11. Business Method Patent Improvement Act of 2000, H.R. 5364, 106th Cong. (2000) (introduced by the Honorable Howard Berman on Oct. 3, 2000).

12. See id. §3.

13. See 35 U.S.C.A. $\$ 273$ (West Supp. 2000). 
the appropriate scope. This analysis continues addressing anticipated concerns about the proposed patent bounty in part VI.

\section{CORE PRECEPTS OF PATENT LAW AND ECONOMICS}

\section{A. Collective Action in Innovation}

Like other goods, innovative products and processes may be analyzed in terms of two economic characteristics. The first is whether the benefits of the good are excludable. ${ }^{14}$ The owner of a bottle of wine may prevent others from drinking, but the producer of radio signals broadcasts for all to hear. The second trait is whether consumption of the good is rivalrous. ${ }^{15}$ If one person's use of the good necessarily diminishes the benefits of another's use, then it is said to be a rival good. For nonrival goods such as pleasing parkway scenery, all may benefit irom the good without diminishing the benefits of others.

Goods vary in their degrees of excludability and rivalrousness. Those that are fully nonexcludable and nonrivalrous are termed public goods. ${ }^{16}$ The production of public goods is subject to market failure, for their nonexcludable and nonrival traits suggest that they will be underproduced relative to social need. ${ }^{17}$ Potential producers of public goods are uncertain whether they will benefit from the good sufficiently to justify their labors. ${ }^{18}$ They would also prefer to free ride off the labors of others, certain that they can enjoy the benefits of the good once someone else builds it. ${ }^{19}$ Individuals will therefore tend to produce goods with greater excludability and rivalrousness. ${ }^{20}$

The production of desirable public goods is said to present a problem of collective action. ${ }^{21}$ Society as a whole favors the development of certain public goods, ranging from military defense to flood control projects. $^{22}$ Private citizens may lack sufficient incentives to produce them, however, leading to suboptimal social outcomes. Government is uniquely suited towards solving collective action problems by modifying individual incentives to engage in desirable behavior. ${ }^{23}$

The patent system is exemplary of this sort of market intervention. As information products, inventions exhibit the characteristics of public goods. ${ }^{24}$ They are nonexcludable, for whether the invention consists of a

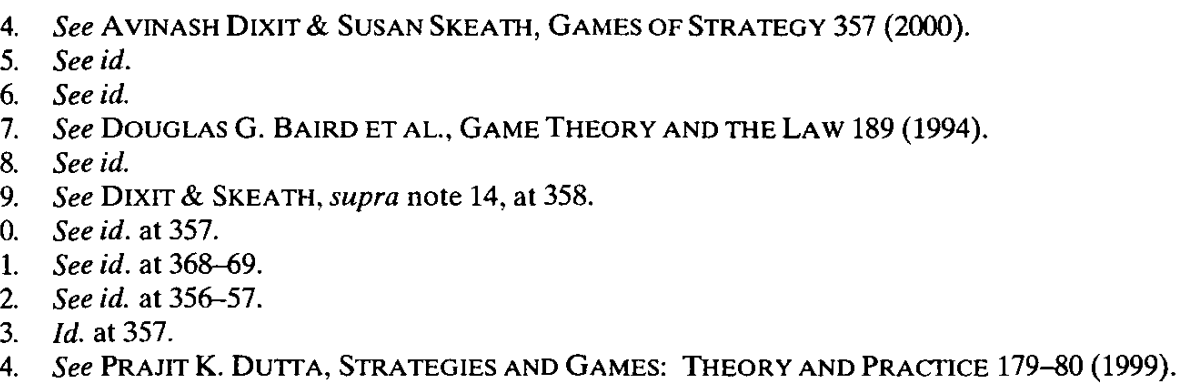


new machine, molecule or merchandising concept, others who learn of its nature may become imitators. ${ }^{25}$ They are also nonrival, for competitive uses do not impact an inventor's personal ability to exploit the invention. ${ }^{26}$ These externalities are said to discourage inventive activity and diminish progress.

The patent law ameliorates this market failure by allowing individuals to obtain proprietary rights in their inventions. ${ }^{27}$ This property rule entitlement creates excludability for patented information products, allowing inventors to prevent free riders from benefiting from their inventions. ${ }^{28}$ By diminishing the public goods aspects of inventions, the patent system encourages individuals to increase their investment in innovative activities.

Patent rights do not arise automatically. Ideally, proprietary rights would be awarded only to those inventors who were actually motivated by the prospect of obtaining a patent, rather than those who acted due to market forces or scientific curiosity, or who enjoyed the happy accident of serendipitous invention. ${ }^{29}$ With individual inducement difficult to ascertain, in practice the Patent Office employs more humble mechanisms for determining whether to award a patent or not. Following the submission of a patent application, an examiner will consider whether the application fully discloses and distinctly claims the invention. ${ }^{30}$ The examiner will also determine whether the claimed invention itself meets certain substantive standards set by the patent statute. ${ }^{31}$ To be patentable, the claimed invention must possess utility, comprise statutory subject matter, and be both novel and nonobvious in view of knowledge within the public domain. ${ }^{32}$

These four substantive requirements weigh unevenly in the patentability determination. For most inventions, the utility and statutory subject matter inquiries play only a minor role in deciding whether a patent should issue or not. ${ }^{33}$ These standards have not always been so leni-

25. See id.

26. E.g., DiXIT \& SKEATH, supra note 14, at 357; DUTTA, supra note 24, at 179-80.

27. See 35 U.S.C. $\$ 271$ (a) (Supp. IV 1998) (providing patentee with exclusive rights to make, use, offer to sell, or sell within the United States, or import into the United States, the patented invention).

28. See Thomas A. MANDEVIlle, Understanding Novelty: InFormation, TechNologiCal Change AND the Patent System 92-93 (1996).

29. See A. Samuel Oddi, Un-Unified Economic Theories of Patents-The Not-Quite-Holy Grail, 71 Notre DAME L. REV. 267, 277-81 (1996).

30. See 35 U.S.C. § 112 (1994).

31. These requirements apply to so-called utility patents. The patent statutes also allow for design patents, see 35 U.S.C. \$ 171 (1994), and plant patents, see 35 U.S.C. § 16. Subject matter and other patentability standards differ somewhat for these more specialized patent regimes.

32. See MARTin J. Adelman ET AL., CASES AND MATERIALS ON PATENT LAw 2 (1998).

33. See Robert P. Merges, Commercial Success and Patent Standards: Economic Perspectives on Innovation, 76 CAL. L. REV. 805, 811-12 (1988); Thomas, supra note 1, at 1160. 
ent. A brief review of the case law suggests their increasing minimalization under the stewardship of the Federal Circuit. ${ }^{34}$

In its 1966 decision in Brenner v. Manson, ${ }^{35}$ the Supreme Court first employed the utility requirement to affirm the rejection of a patent application. There the applicant claimed a steroid that was structurally similar to a compound known to inhibit tumors in mice. At the time the patent application was filed, however, no use for the claimed steroid yet had been discovered. ${ }^{36}$ The Court affirmed the Patent Office rejection of the application, explaining that in order to possess utility within the meaning of the patent statute, an invention must confer a "specific benefit ... in currently available form." 37

Brenner v. Manson had great impact in the chemical arts, where researchers frequently generate compounds with unknown behaviors. ${ }^{38}$ Such compounds are often structurally similar to known chemicals with beneficial properties. ${ }^{39}$ Typically researchers hope that the new compounds have superior properties or lack the undesirable side effects of the known chemical. The behavior of chemical compounds is often predictable, however, and only subsequent testing will tell whether the compound has any desirable properties at all. ${ }^{40}$ Here the Supreme Court instructed inventors to delay filing a patent application until that determination has been reached. ${ }^{41}$ Brenner $v$. Manson provided a powerful tool for rejecting patents on human gene fragments, chemicals, and other products with unknown uses.

Brenner v. Manson can now be seen as the high-water mark of the utility requirement. ${ }^{42}$ The Federal Circuit case law has significantly retreated from this standard. The leading Federal Circuit opinion on utility, In re Brana,$^{43}$ also concerned an application claiming a chemical compound. The applicant asserted the compound acted as an antitumor agent, citing a structurally similar compound that exhibited this behavior. ${ }^{44}$ The Patent Office held that these assertions were too vague and suffered from lack of proof of a therapeutic utility. ${ }^{45}$ The Federal Circuit

34. Although this discussion applies to most fields amenable to patenting, the force of the patentability requirements differs in some disciplines. In particular, the nonobviousness standard appears quite lenient for certain biotechnologies, see In re Deuel, 51 F.3d 1552, 1558 (Fed. Cir. 1995), while the written description requirement may be of greater significance, see Fiers v. Revel, 984 F.2d 1164, 1170 (Fed. Cir. 1993).

35. 383 U.S. 519 (1966).

36. See id. at 531 .

37. Id. at 534-35.

38. See 1 DONALD S. ChISUM, PATENTS $\$ 4.02[2]$ (2000).

39. See id.

40. See id.

41. See Brenner, 383 U.S. at 534-35.

42. See Phanesh Koneru, To Promote the Progress of Useful Art/icle]s?: An Analysis of the Current Utility Standards of Pharmaceutical Products and Biotechnological Research Tools, 38 IDEA 625, 628 (1998)

43. 51 F.3d 1560 (Fed. Cir. 1995).

44. See id. at 1562-63.

45. See id. at 1563-64. 
reversed the Patent Office rejection, holding that the compound's structural similarity to known, useful compounds sufficiently evidenced utility. ${ }^{46}$

Brana and Brenner v. Manson are difficult to reconcile. The Federal Circuit apparently thought so as well, for the Brana decision neglects even to cite Brenner v. Manson. ${ }^{47}$ The Brana court's further statement that " $\mathrm{t}]$ he purpose of treating cancer with chemical compounds does not suggest an inherently unbelievable undertaking or involve implausible scientific principles" suggests a greatly diminished role for the utility requirement even in the chemical, pharmaceutical, and biotechnological arts. $^{48}$ For most inventions, the utility requirement now appears to be satisfied by only a minimal showing that the invention is operable and provides a tangible benefit. ${ }^{49}$

More famously, the statutory subject matter requirement too has become exceptionally lenient. The patent statute allows a patent to issue for a "process, machine, manufacture, or composition of matter." Despite the breadth of this language, courts traditionally limited the patent system to industrial technologies. ${ }^{51}$ Products and processes that systematically manipulated external physical forces in order to modify or fabricate artifacts were judged patentable subject matter. ${ }^{52}$ Excluded were matters of personal skill, aesthetics, commercial strategy, and human behavior. ${ }^{53}$

The decision of the Federal Circuit in State Street Bank \& Trust Co. v. Signature Financial Group, Inc. breached this traditional barrier to patenting. ${ }^{54}$ In State Street Bank, the court held that a data processing system for managing a mutual fund constituted patentable subject matter. ${ }^{55}$ Rejecting the venerable "business methods" exception to patentability, the Federal Circuit held that the key inquiry concerning statutory subject matter involves "the essential characteristics of the subject matter, in particular, its practical utility." 56 By collapsing the statutory subject matter and utility requirements, State Street Bank opened the patent system to inventions from the entire range of human endeavor.

46. See id. at $1566-67$.

47. See Nathan Machin, Prospective Utility: A New Interpretation of the Utility Requirement of Section 101 of the Patent Act, 87 CAL. L. REV. 423, 432 (1999).

48. Brana, 51 F.3d at 1566.

49. Although the Patent Office has recently issued Utility Guidelines that suggest a stricter view of the utility requirement, see Revised Utility Examination Guidelines, 64 Fed. Reg. 71,440, 71,441 (Dec. 21, 1999), the Guidelines are not binding upon examiners, and whether or not the Federal Circuit will uphold them remains doubtful.

50. 35 U.S.C. $\$ 101(1994)$.

51. See Thomas, supra note 1 , at $1143-47$.

52. See id.

53. See id.

54. 149 F.3d 1368 (Fed. Cir. 1998), cert. denied, 525 U.S. 1093 (1999).

55. See id. at 1373 .

56. Id. at 1375 . 
Subsequent Federal Circuit decisions have maintained this approach, confirming that "virtually anything is patentable." 57

As a result of the decline of the utility and subject matter requirements, novelty and nonobviousness have come to serve as the principal gatekeepers to the patent system. Each of these requirements calls for a comparison of the requirements that compare the claimed invention with public domain knowledge or, in the vernacular of the patent law, the prior art. For an invention to be novel, the claimed invention must not be wholly anticipated by the teachings of a single, previous technical disclosure. ${ }^{58}$ To fulfill the nonobviousness standard, the claimed invention must not have been within the ordinary capabilities of a skilled artisan at the time it was made, in light of the teachings of the prior art as a whole. ${ }^{59}$

Always a central function of the Patent Office, the task of locating prior art pertinent to each submitted application has assumed even greater significance. The utility and statutory subject matter standards have become increasingly disabled from blocking patents on genetic materials, Internet-based business models, and other inventions of intense public interest. Novelty and nonobviousness stand as the principal mechanisms for denying most patent applications, but these requirements are effective only when the Patent Office knows of prior art applicable to the claimed invention. This article next takes a closer look at core prior art concepts, as well as Patent Office mechanisms for gathering prior art references.

\section{B. Prior Art in the Patent Law}

The patent statute defines the prior art pertinent to each application in $\S 102 .{ }^{60}$ Information meeting the requirements of this provision must be contrasted with the claimed invention in order to decide the issues of novelty and nonobviousness. ${ }^{61}$ Section 102 is long, Byzantine, and not easily susceptible to summary. However, its prior art definition generally includes all patents and printed publications available anywhere, as well as technology known or on sale within the United States. ${ }^{62}$ These references must have been available either prior to the time the invention was made ${ }^{63}$ or more than one year before the inventor filed an application at the Patent Office. ${ }^{64}$ Many of these references are subject to a minimal

57. Hughes Aircraft Co. v. United States, 148 F.3d 1384, 1385 (Fed. Cir. 1998) (Clevenger, J., dissenting from denial of rehearing en banc); see also AT\&T Corp. v. Excel Communications Inc., 172 F.3d 1352, 1361 (Fed. Cir.), cert. denied, 528 U.S. 946 (1999).

58. See 35 U.S.C. $\$ 102$ (1994).

59. See id. §103(a).

60. See id. $\$ 102$.

61. See ADELMAN ET AL., supra note 32, at 205.

62. See 35 U.S.C. \& 102(a)-(b).

63. See id. $\$ 102(\mathrm{a})$.

64. See id. $\$ 102(b)$. 
requirement of public availability. ${ }^{65}$ Section 102 also allows for so-called secret prior art, however, which need not have been publicly accessible at all. $^{66}$.

The $\S 102$ prior art definition is strikingly broad. Every book, journal article, leaflet, and student thesis published anywhere in the world in any language potentially serves as prior art. ${ }^{67}$ Other permissible sources of prior art, such as sales offers or knowledge, need not have been formally documented at all. ${ }^{68}$ The difficulties inherent in obtaining, organizing, and analyzing these diverse sources of prior art should be apparent. ${ }^{69}$

Facing such dispersed knowledge, the Patent Office has developed two principal investigation techniques. First, examiners conduct their own search of the prior art upon turning to each new application. ${ }^{70}$ The Patent Office maintains an impressive library of prior art references in order to assist the examining corps. ${ }^{71}$ Computerized databases additionally allow examiners to search literally millions of domestic and foreign patents, more than 5000 journals and over 900 databases. $^{72}$

Patent Office regulations also require applicants to submit pertinent prior art of which they are aware. ${ }^{73}$ Although the Patent Office does not itself enforce this rule, ${ }^{74}$ an accused infringer may raise the defense of inequitable conduct in court. If the court concludes that the patentee knowingly failed to submit applicable prior art to the Patent Office, then it will hold that the patentee engaged in inequitable conduct and declare the patent unenforceable. ${ }^{75}$ By all accounts inequitable conduct is frequently raised during infringement litigation. ${ }^{76}$ Many Federal Circuit decisions suggest that the applicant's duty to disclose will be strictly enforced. ${ }^{77}$

65. See State Indus., Inc. v. Rheem Mfg. Co., 223 U.S.P.Q. (BNA) 305, 316-17 (M.D. Tenn. 1984), aff'd in part and rev'd in part, 769 F.2d 762 (Fed. Cir. 1985).

66. See 35 U.S.C. \& 102(g); C. Douglas Thomas, Secret Prior Art-Get Your Priorities Straight!, 9 HARV. J.L. \& TECH. 147, 149-51 (1996).

67. See In re Hall, 781 F.2d 897, 898-900 (Fed. Cir. 1986).

68. See 35 U.S.C. $§ 102$ (b); Pfaff v. Wells Elecs., Inc., 525 U.S. 55, $67-69$ (1998).

69. See Nard, supra note 8, at 783-85.

70. See generally id. at 777 (discussing patent invalidity determinations based on prior art not considered by the PTO during prosecution of the patent).

71. See generally Stephen L. Noe \& Alan J. Riddles, A "Searching" Examination of USPTO, JPO, EPO and Commercial Data Bases, in ELECTRONIC AND COMPUTER PATENT LAW 205, 227-31 (PLI Patents, Copyrights, Trademarks \& Literary Prop. Course Handbook Series No. 292, 1990).

72. See Bruce Kisliuk \& Jessie Marshall, Business Is Booming, PTO TODAY, Jan. 2000, at 17, 19.

73. See ADELMAN ET AL., supra note 32, at 736.

74. See id. at 746.

75. See id.

76. See Burlington Indus. v. Dayco Corp., 849 F.2d 1418, 1422 (Fed. Cir. 1988) ("[T]he habit of charging inequitable conduct in almost every major patent case has become an absolute plague.").

77. E.g., Semiconductor Energy Lab. Co. v. Samsung Elecs. Co., 204 F.3d 1368, 1377 (Fed. Cir. 2000); Elk Corp. v. GAF Bldg. Materials Corp., 168 F.3d 28, 30 (Fed. Cir. 1999); Baxter Int'l, Inc. v. McGaw, Inc., 149 F.3d 1321, 1329-30 (Fed. Cir. 1998); Rohm \& Haas Co. v. Brotech Corp., 127 F.3d 1089, 1093 (Fed. Cir. 1997); Refac Int'l, Ltd. v. Lotus Dev. Corp., 81 F.3d 1576, 1581 (Fed. Cir. 1996); Molins PLC v. Textron, Inc., 48 F.3d 1172, 1178 (Fed. Cir. 1995); General Electro Music Corp. v. 
Experience suggests that there is ample room for improvement in these two information-gathering techniques. The vast Patent Office bibliographic resources are balanced by its lack of inquisitorial powers. ${ }^{78}$ Absent the ability to compel the disclosure of pertinent facts, examiners are virtually unable to locate undocumented or secret prior art. ${ }^{79}$ Examiners must also take applicants at their word when they attest to such significant facts as dates of inventive activity, ${ }^{80}$ indicia of nonobviousness ${ }^{81}$ or the derivation of a prior art reference. ${ }^{82}$

The Patent Office is also notorious for its tight employee schedules. $^{83}$ Examiners are allowed only a limited time to sift through enormous amounts of prior art information. ${ }^{84}$ The exact amount of time allocated to individual examiners per application is not widely understood outside of the Patent Office. The precise formulae are held close to the vest by Patent Office management. Apparently, they are also surprisingly complex, accounting for international treaties, examiner seniority, the technical complexity of the discipline, and other factors. ${ }^{85}$ However, the average time allocated for an examiner to address one application is understood to be between sixteen and seventeen hours. ${ }^{86}$ Given the complexities involved in parsing an application, conducting a prior art search and drafting an Office Action, this period is surprisingly short.

Applicant disclosures tend to fall in a bimodal distribution, with either a minimal number of submitted references or a very large number. ${ }^{87}$ A review of Rule 56 explains this feast or famine effect. Although Rule 56 mandates that applicants disclose known prior art, it does not require them to search the prior art in the first place. ${ }^{88}$ Coupled with the draco-

Samick Music Corp., 19 F.3d 1405, 1408 (Fed. Cir. 1994); Paragon Podiatry Lab., Inc. v. KLM Labs., Inc., 984 F.2d 1182, 1193 (Fed. Cir. 1993).

78. See In re Huang, 100 F.3d 135, 139 (Fed. Cir. 1996).

79. See id. at $139-40$.

80. See Patent \& TRAdemark OfFICE, U.S. DeP'T OF Commerce, MaNual of Patent ExAMINING PROCEDURE $\$ 715.07$, at 700-139 (7th ed. 1998) (stating that, with respect to proof of dates of inventive activity, the Patent Office allows applicants to redact dates from proffered exhibits and "merely allege that the acts referred to occurred prior to a specified date") [hereinafter MANUAL OF PATENT EXAMINING].

81. See id. $\$ \$ 716$ to 716.03 , at $700-142$ to $700-152$.

82. See id. $\$ 716.02(\mathrm{e})$, at $700-148$ to $700-149$.

83. See Kevin Coughlin, Technology Upends the Meaning of Invention: Patent Requests Shift to Ideas, Know-how, THE STAR-LEDGER (Newark), Mar. 12, 2000, available at 2000 WL 15869531 (describing statement by Ronald Stern, President of the Patent Office Professional Association, that workdays are broken into six-minute increments, and employees are pressed to work quickly).

84. See Vasu Jagannathan, Perspectives on U.S. Classification, 82 J. PAT. \& TRADEMARK OFF. SoC'Y 366 (2000); Paul M. Janicke, Do We Really Need So Many Mental and Emotional States in United States Patent Law?, 8 TEX. INTELL. PROP. L.J. 279, 292 n.60 (2000).

85. See Interview with Mr. Ronald J. Stern, President, Patent Office Professional Association, in Arlington, Va. (June 29, 2000).

86. See id.

87. See generally Scott D. Anderson, Comment, Inequitable Conduct: Persistent Problems and Recommended Solutions, 82 MARQ. L. REV. 845 (1999) (discussing the disclosure consequences from a finding of inequitable conduct).

88. See id. at 852 . 
nian consequences of a holding of inequitable conduct, ${ }^{89}$ many applicants are discouraged from conducting prior art searches in the first place. Concerned that the failure to disclose a known reference will lead to the unenforceability of the patent, some applicants prefer to await the examiner's search results rather than consult the prior art themselves. ${ }^{90}$

Where the applicant is already well informed of the prior art, the specter of inequitable conduct too often causes applicants to submit virtually every reference of which they are aware. ${ }^{91}$ Examiners must then confront dozens of marginal references rather than a handful of the most pertinent ones. ${ }^{92}$ Coupled with the severe time constraints facing the examining corps, this overload of information often allows no more than a cursory review of all but a few references that initially appear the most promising.

Many litigated cases betray the weaknesses of present Patent Office prior art collection techniques. ${ }^{93}$ Among the defenses available to the accused infringers is that the asserted patent is invalid. ${ }^{94}$ This defense may be based solely upon prior art considered by the Patent Office. ${ }^{95}$ But the usual defendant is able to locate additional prior art that was not before the examiner..$^{96}$ A recent study indicates that defendants most often turn to previously uncited prior art when raising an invalidity defense, and that they are more likely to be successful when they do. ${ }^{97}$

Thus, virtually every patent infringement trial becomes an occasion for attacking the quality of Patent Office work product. Still, continuing commentary contends that the ability of the Patent Office to locate prior art pertinent to filed applications is increasingly suspect. ${ }^{98}$ At a time when legal trends have diminished those patentability standards that do

\footnotetext{
89. See id. at 861.

90. See generally id. at 852-53 (suggesting implicitly that applicants will await the examiner's search rather than do it themselves).

91. See generally id. at 845-76 (discussing effects of a finding of inequitable conduct).

92. See Donald E. Egan, Preparing and Prosecuting a Patent To Win in Litigation, in WINNING Strategies in Patent Litigation 9, 30 (Pli Patents, Copyrights, Trademarks \& Literary Prop. Course Handbook Series No. 423, 1995) ("[T]he best practice would be to call the examiner's attention to every piece of even remotely relevant prior art as soon as it becomes known to the applicant or his attorney."); see also Gary M. Hoffman \& Michael C. Greenbaum, The Duty of Disclosure Requirements, 16 AM. INTELL. PROP. L. Ass'N Q.J. 124, 149 (1988) ("Since patent practitioners cannot predict what a 'reasonable' examiner will find to be 'material,' all known information relating to the application at hand, namely prior art, prior patents, publications, etc., should be brought to the attention of the PTO in order to avoid a later charge, either by the PTO or during litigation, of inequitable conduct.").

93. See Donald R. Dunner et al., A Statistical Look at the Federal Circuit's Patent Decisions: 1982-1994, 5 FED. CIR. B.J. 151, 158, 163 (1995) (finding that the Federal Circuit held patents invalid under $\S 102$ in 87 cases and invalid under $\S 103$ in 132 cases issued from Oct. 1, 1982, through Mar. 15,

94. See John R. Allison \& Mark A. Lemley, Empirical Evidence on the Validity of Litigated Patents, 26 AM. INTELL. Prop. L. Ass'N Q.J. 185, 228 (1998).

95. See id. at 228-29.

96. See id. at 231-34.

97. See id. at 207-11.

98. See Merges, supra note 5, at 589.
} 1994). 
not depend upon the prior art, this trend may have severe consequences for innovative sectors of our economy. This article takes up the causes and implications of our present patent quality problems next.

\section{The PATENT QUALITY CRISIS}

Business is booming at the Patent Office. The patent application filing rate has increased at a rate of at least eight percent per year since the mid-1990s, with a thirteen percent growth rate in the 1999 fiscal year. ${ }^{99}$ The Patent Office forecasts receipt of 335,400 patent applications in 2001, a seventy-five percent increase in five years. The strong performance of the U.S. economy and strengthening of foreign patent regimes provide some explanation for the growing number of patent applications. ${ }^{100}$ Perhaps the most telling factors, however, have been the dramatic expansion of patentable subject matter and the diminution of the utility requirement. With industry routinely seeking patent protection for gene sequences, software, business methods, and other postindustrial inventions, the number of stakeholders in the patent system has greatly expanded in recent years.

At first blush, increasingly permissive Patent Office practices towards statutory subject matter would seem an astoundingly successful case of agency expansion of its own jurisdiction. ${ }^{101}$ This mission creep should have brought tremendous financial benefits for the Patent Office. With patent application and other user fees comprising its entire source of revenue, ${ }^{102}$ the Patent Office should literally be awash in funds. In fact, the Patent Office finds itself increasingly impoverished during a crucial moment for our intellectual property law. ${ }^{103}$ Growing congressional reliance upon the inventive community to fund the public fisc has transformed the Patent Office from loss leader to public revenue source. The causes and effects of the current lean times at the Patent Office are worthy of explanation.

For most of its history, the Patent Office charged filing, issuance, and other fees that were insufficient to cover its expenses. ${ }^{104}$ Congress allocated additional taxpayer funds to make up the deficit. ${ }^{105}$ Facing in-

99. See Kisliuk \& Marshall, supra note 72 , at 17.

100. See id. at 18.

101. See John R. Thomas, Patents and E-Commerce: The United States Experience Post-State Street Bank, 16 INTELLECTUELE EIGENDOM \& RECLAMERECHT 116, 123 (2000).

102. See Legislation: Patent and Trademark Office: Witnesses Testify on Diversion of Patent Office Fees and Business Method Patents, 59 Pat. Trademark \& Copyright J. (BNA) 659 (2000).

103. See Hayden Gregory, Congress Slows Pace on IP Legislation, Struggles with PTO User Fee Dilemma, Marshall L. SCh. CENTER FOR INTEll. Prop. L. News SourCe 2, 4-5 (Spring 2000), available at http://www.jmls.edu/IP/April\%20IP\%newsletter.pdf.

104. See id. See generally Valerie Calloway, In the Process of Controverting Its Constitutionally Given Purpose the U.S. Patent System Discriminates Against Inventors with Limited Financial Means, 11 LAW \& INEQ. 565, 571-75 (1993).

105. See Gregory, supra note 103 , at 3 . 
creasing budgetary pressures in 1982, however, Congress endeavored to diminish taxpayer support of Patent Office activities. Although public revenue continued to fund such Patent Office divisions such as legislative and international affairs, applicant fees were significantly increased in order to cover all application processing expenses. ${ }^{106}$ Patent Office fee revenues first made their way to the Treasury, but Congress annually appropriated all of the collected monies back to the Patent Office. ${ }^{107}$

Congress again altered the Patent Office fee schedule in the Omnibus Budget Reconciliation Act of 1990. That legislation created a fee surcharge, amounting to an increase of approximately sixty-seven percent over previous levels, intended to make the Patent Office wholly user funded. ${ }^{108}$ Congress called for the income from the Patent Office surcharge to flow to a discrete Treasury account. ${ }^{109}$ Although Congress initially gave all of the surcharge fund back to the Patent Office, the fund proved an increasingly attractive source of revenue throughout the 1990's. ${ }^{110}$ By the time the surcharge scheme expired in 1998, Congress had diverted over \$234 million in Patent Office fees to other government programs. ${ }^{111}$

Although many in the patent community lauded the end of the surcharge, this event led only to more ingenious legislative accounting mechanisms for diverting Patent Office fees. During the 2000 fiscal year, for example, Congress placed a ceiling of $\$ 775$ million upon the amount of fee revenue that the Patent Office may spend. ${ }^{112}$ This sum is approximately $\$ 290$ million less than expected Patent Office revenues. ${ }^{113}$ Although some of this shortfall may be reallocated to the Patent Office during the 2001 fiscal year, Congress appears poised both to limit such reallocations and to place more aggressive budgetary ceilings upon the Patent Office in the near future. ${ }^{114}$ Numerous Patent Office programs have inevitably suffered from these budgetary setbacks. The Patent Office has identified such programs as the expansion of prior art databases, quality assurance, and the hiring and training of examiners as deleteriously impacted by miserly financial policies. ${ }^{115}$

Among the treasured anecdotes of the U.S. patent system is the survival of the Patent Office during the 1814 sack of Washington, D.C. Following the British assault on Washington, D.C., the only significant public building to survive was Blodgett's Hotel, home of the Patent Of-

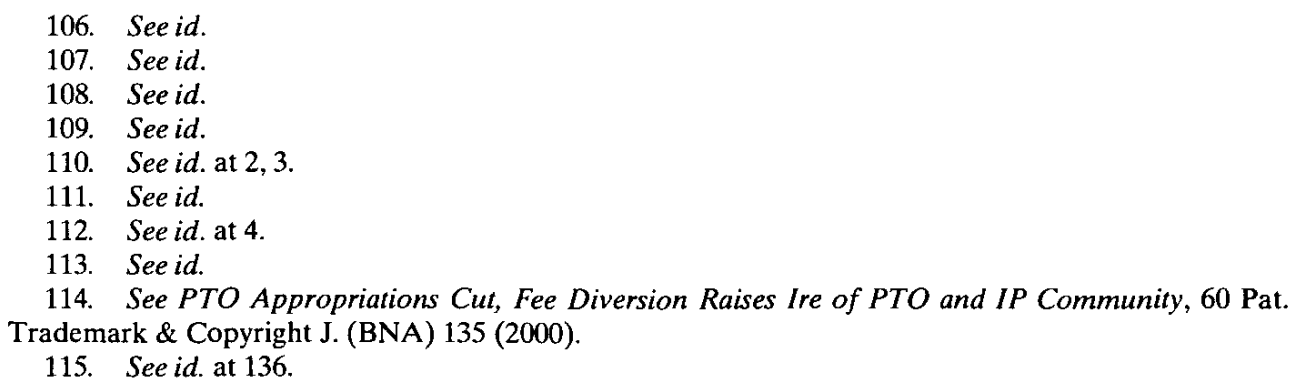


fice. ${ }^{116}$ The forbearance of the British army has been owed to the impassioned pleas of a Dr. William Thornton, who argued that the pillaging of the Patent Office would be akin to the destruction of the ancient Library at Alexandria. ${ }^{117}$ Regrettably, congressional financial authorities have shown considerably less restraint than did the British that day.

In combination with the declining significance of the utility and statutory subject matter requirements, meager Patent Office funding has had a felt impact upon patent quality. Observers have reported that an increasingly high percentage of issued patents appropriate concepts that previously entered the public domain. ${ }^{118}$ A common parlor trick at intellectual property conferences is to display the latest issued patent that cites only a modest number of prior art references. The next slide invariably demonstrates a wholly anticipatory reference from a widely circulated source.

Persistent commentary also reports that the Patent Office has increasingly relied upon previously issued patents as prior art. ${ }^{119}$ Newly granted patents stress the citation of prior art patents, with diminished reference to such secondary literature as texts and journal articles. ${ }^{120}$ Tight examiner schedules appear to be the chief cause of this circumscribed searching strategy. In comparison to much of the secondary literature, patents are readily accessible, conveniently classified and printed in a common format. Identification of a promising secondary reference, and full comprehension of its contents, often prove to be more difficult tasks.

A prior art search focused upon granted patents may not be entirely objectionable in fields in which patents have been traditionally sought. Patents provide a robust prior art database in many disciplines. As well, a virtue of the nonobviousness standard is that an examiner need not locate the ideal anticipatory prior art reference in order to reject an application over the state of the art. Several related references may provide a view of public domain knowledge sufficient to generate a valid rejection.

Overreliance upon patents as indicia of the state of the art works far more mischief in fields long believed to be outside the patent system, however. For software, business methods, and other postindustrial inventions, the repository of issued patents insufficiently samples the prior art. Examiners who primarily rely upon the patent literature to generate

116. See Whit Cobb, Democracy in Search of Utopia: The History, Law and Politics of Relocating the National Capital, 99 DICK. L. REV. 527, 551 (1995).

117. See KenNeTH W. Dobyns, The Patent OFfice Pony: A History of the Early Patent OFFICE 64-66 (1997).

118. See Andy Johnson-Laird, Looking Forward, Legislating Backward?, 4 J. SMALL \& EMERGING Bus. L. 95, 120 (2000); Wayne M. Kennard, Software Patents As a Weapon: Are You Ready to Rumble?, in 19TH ANNUAL INSTITUTE ON COMPUTER LAw 1123, 1135 (PLI Patents, Copyrights, Trademarks \& Literary Prop. Course Handbook Series No. 547, 1999).

119. See Kennard, supra note 118, at 1135.

120. See id. 
prior art in these fields are quite likely to allow patents to issue based upon information already within the public domain. Even those diligent examiners who consult the nonpatent literature might be limited to a sparse prior art collection. Because the patentability of business methods was unclear prior to the Federal Circuit's State Street Bank ${ }^{121}$ decision, for example, the Patent Office has yet to develop a comprehensive library of prior art business materials. ${ }^{122}$

Some commentators have suggested that these problems are merely transitional in character. ${ }^{123}$ Under this view, Patent Office examiners will be able to climb the learning curve of business methods patents over time, just as they have with new technologies in the past. ${ }^{124}$ However, prior art within disciplines newly opened to patenting may prove to be more elusive than traditionally patentable inventions. Business practices are discerned by observing the conduct of commercial enterprises, rather than by reading technical publications. ${ }^{125}$ The norms of the scientific community, which call for disclosure and peer review of advances, are not necessarily shared by the commercial sector. Of course, while such practices comprise prior art, ${ }^{126}$ they are not readily located by Patent Office examiners.

Longstanding limitations upon Patent Office resources have resulted in the issuance of invalid patents before. In many cases, the Patent Office error is harmless. Many patents claim inventions that nobody seriously intends to commercialize. ${ }^{127}$ Scorched earth prior art searches for recently issued patents on a motorized ice cream cone, ${ }^{128}$ hyper-lightspeed antenna, ${ }^{129}$ and a method of exercising a cat, ${ }^{130}$ for example, were unlikely to present an efficient use of Patent Office resources.

Considerable social costs may attend the improvident issuance of many patents, however. Industry participants may be forced to expend considerable sums litigating or licensing invalid patents. Others may avoid market or research activities out of recognition of the vagaries of litigation results and the possibility of infringement liability. Attracted by large damages awards and loose Patent Office standards, rent-seeking

121. 149 F.3d 1368 (Fed. Cir. 1998), cert. denied, 525 U.S. 1093 (1999).

122. See Jenna Green, Staking a Claim, Legal Times IP MAG., Apr. 10, 2000, at 14.

123. See John Schwartz, Online Patents to Face Tighter Review, WASH. POST, Mar. 30, 2000 , at E1.

124. See id.

125. See Rochelle Cooper Dreyfuss, Are Business Method Patents Bad for Business?, 16 SANTA Clara COMP. \& High TECH. L.J. 263, 269 (2000).

126. See 35 U.S.C. $\$ 102(1994)$.

127. A. Samuel Oddi, An Uneasier Case for Copyright than for Patent Protection of Computer Programs, 72 NEB. L. REV. 351, 426 (1993) ("[M]any patented inventions are never marketed for consumption.").

128. U.S. Patent No. 5,971,829 (issued Oct. 26, 1999).

129. U.S. Patent No. 6,025,810 (issued Feb. 15, 2000).

130. U.S. Patent No. 5,443,036 (issued Aug. 22, 1995). 
entrepreneurs may divert resources from productive activities into speculative patent acquisition and enforcement ventures. ${ }^{131}$

The stakes may be even higher for patents in the areas of business methods and software. ${ }^{132}$ Professor Rochelle Dreyfuss has observed that business method and data transformation patents concern information rather than industrial products. ${ }^{133}$ Such products tend to exhibit lock-in and network externalities. ${ }^{134}$ Lock-in occurs when consumers face high costs in switching from one brand of technology to another. ${ }^{135}$ Network externalities result from a situation of positive feedback, where the value of connecting to a network depends upon the number of other people also connected to that network. Applied to economic competition, the typical result of network effects is a monopolistic, winner-take-all market. Telephony and computer operating systems present examples of markets with network externalities. ${ }^{136}$

These economic characteristics of information products suggest that software and business method patents need not be considered valid for very long in order to have substantial market impact. ${ }^{137}$ Suppose, for example, that an Internet-based electronic retailer obtains a patent on a method of ordering merchandise, conducting an auction or enlisting associated retailers. Such patents may be invalid because they merely claim obvious electronic variants of well-known commercial activities. However, competitors of the patentee may face delays of several years as they seek to strike down such patents. Indeed, the high costs of patent litigation may discourage other retailers from challenging a patent at all. ${ }^{138}$ As a result, competitors of the patentee may be discouraged from engaging in the patented method. Consumers who wish to take advantage of the patented business features must then transact with the patentee.

The resulting market distortions may be significant. Familiarity with the patentee's website may encourage consumers to maintain commercial relationships with the patentee, even if competitive websites later

\footnotetext{
131. See Merges, supra note 5, at 592 .

132. Improvidently granted patents may also have a disproportionate impact upon the pharmaceutical industry. Under the Hatch-Waxman Act, the Food and Drug Administration may not ordinarily issue marketing approval of an abbreviated new drug application for thirty months following the commencement of patent enforcement litigation. See The Drug Price Competition and Patent Term Restoration Act of 1984, Pub. L. No. 98-417, 98 Stat. 1585 (codified at 21 U.S.C. $\$ 355$ (c)(3)(C), (j)(5)(B)(iii) (1994 \& Supp. IV 1998)). This provision effectively grants a drug patent owner a thirtymonth preliminary injunction without any judicial assessment of the enforceability of the patent. See Alfred B. Engelberg, Special Patent Provisions for Pharmaceuticals: Have They Outlived Their Usefulness?, 39 IDEA 398 (1999).

133. See Dreyfuss, supra note 125, at 271.

134. Carl Shapiro \& Hal R. Varian, Information Rules: A Strategic Guide to the NETWORK ECONOMY 103-04, 173-75 (1999).

135. See id. at 104.

136. See id. at 174-75.

137. See Dreyfuss, supra note 125 , at $271-72$.

138. See id. at 270.
} 
enter the market. For example, Professor Dreyfuss observes that once consumers have entered their name, address, and billing information into a patentee's website, they may be reluctant to engage in the same tedious task with another Internet retailer. ${ }^{139}$ As a result, the consumer is locked into the website of the patentee even if the patent is later invalidated.

Network effects may also play a role here. Internet retailers often analyze the information they receive from consumers in order to predict additional products individual consumers might enjoy. The accuracy of these predictions depends in part upon the number of consumers. Thus, the larger the network of consumers who patronize a particular website, the more valuable it is to patronize that website. ${ }^{140}$ Internet auction houses operate more effectively with more prospective sellers and bidders available. In sum, patent rights, even ones of dubious validity and limited lifespan, appear to accelerate the anticompetitive aspects of information products.

Traditional technologies often exhibit lock-in and network effects as well. The role of information economics should not be overstressed in this context. A leading Supreme Court patent case from the nineteenth century, the Telephone ${ }^{141}$ case, was perhaps the fountainhead of the Bell monopoly. The Patent Office could rely upon its expertise with predecessor electrical circuitry when considering this technology, however. Today examiners are confronted with inventions from the law, psychology, insurance, and other disciplines that are neither technological nor the subject of any Patent Office experience. ${ }^{142}$ The current fiscal limitations upon the Patent Office are also without precedent. It is this combination of forces that has placed increasing stress upon our patent system.

The patent quality crisis is worthy of our attention. The market impact of business method patents alone has yet to be quantitatively assessed, but decisions such as Amazon.com v. Barnesandnoble.com suggest staggering possibilities. ${ }^{143}$ In that case Amazon.com obtained a patent claiming a method of ordering merchandise on the Internet with a single action, such as one click of a mouse button. Yet anyone who has walked into a bar, been spotted by a familiar bartender, and placed an order along with a request to "Put it on my tab!" seems to have engaged in one-click ordering. Amazon.com's patent rights nonetheless resulted in the award of a preliminary injunction against a major competitor on the eve of an all-important holiday shopping season.

\footnotetext{
139. See id. at 271.

140. See id.

141. See Dolbear v. Am. Bell Tel. Co., 126 U.S. 1 (1887).

142. See Thomas, supra note 1, at 1163.

143. 73 F. Supp. 2d 1228 (W.D. Wash. 1999). The Federal Circuit subsequently vacated the preliminary injunction in Amazon.com, Inc. v. Barnesandnoble.com, Inc, No. 00-1109 (Fed. Cir. Feb. 14, 2001). The Federal Circuit concluded that Barnesandnoble.com had mounted a substantial challenge to the validity of the one-click patent. Although the Federal Circuit reached the appropriate result, it is regrettable that an improvidently issued patent afforded Amazon.com the benefit of an improvidently granted injunction for fourteen months and the passing of two holiday shopping seasons.
} 
Amazon.com suggests the deleterious consequences associated with the appropriation of computerized versions of familiar business activities. Commentators have passionately urged that the patenting of electronic commerce patents runs counter to norms of open access to the Internet. ${ }^{144}$ Concern that the principal tools of the Internet economy will be appropriated by a few has also led to predictions of diminished competition in online commerce. ${ }^{145}$

Another worrisome trend is that public perception of the patent system is in a rapid tailspin. Citing proprietary rights in electronic commerce concepts such as the one-click patent, major newspapers and magazines have once more found the patent system a convenient target of scathing criticism. ${ }^{146}$ Amazon.com itself faced public protest and talk of a boycott following its successful patent enforcement exercise. ${ }^{147}$ Conciliatory statements by Amazon.com CEO and Time Magazine 1999 Person of the Year Jeffrey Bezos dampened this movement, ${ }^{148}$ but his remarks appear to have set another sequence of events into motion. By suggesting that the patent law be modified to account for software and business methods, ${ }^{149}$ Bezos has renewed vigorous discussion over the substance and procedure of contemporary patent law. This article next considers the modern patent law reform movement, identifying and analyzing some of the more significant proposals.

\section{A ReVIEW of PreVAiling PATENT REForm PRoposals}

With the patent system plumbing depths not seen since the Great Depression, a surfeit of proposals have emerged for solving the current troubles of the patent system. The Patent Office itself has launched a multifaceted Business Methods Patent Initiative aimed at improving patent quality. Academic journals and the lay press alike have offered more dramatic measures meant to improve upon patent acquisition and enforcement. This part offers a critical review of the more popular reform proposals on the table, with emphasis upon the most popular of the lot, the opposition.

144. See Tim O'Reilly, My Conversation with Jeff Bezos, at http://www.Oreilly.com/ask_tim.html (Mar. 2, 2000) (on file with the University of Illinois Law Review).

145. See Lawrence Lessig, The Problem with Patents, THE INDUS. STANDARd, at http://www.thestandard.com/article/display/0,1151,4296,00.html (April 23, 1999) (on file with the University of Illinois Law Review).

146. See Jan Muehlbauer, Patent Pundits on Parade, THE INDUS. STANDARD, at http://www.thestandard.com/article/display/0,1151,13019,00.html (Mar. 16, 2000) (on file with the University of Illinois Law Review).

147. See Richard M. Stallman, Boycott Amazon!, Free SoFTware Foundation, at http://www.gnu.org/philosophy/amazon.html (last updated June 15, 2000) (on file with the University of Illinois Law Review).

148. Jeff Bezos, An Open Letter from Jeff Bezos on the Subject of Patent, at http://www.amazon .com/exec/obidos/subst/misc/patents.html (last visited Aug. 21, 2000) (on file with the University of Illinois Law Review).

149. See id. 


\section{A. The Initiative and Related Reform Proposals}

On the heels of a congressional oversight hearing that called the quality of business methods patents into question, the Patent Office on March 29, 2000, launched a "Business Methods Patent Initiative."150 According to the Patent Office, the Initiative will "ensure that patents granted for software-implemented business methods are of the highest quality and benefit to the growing electronic commerce industry." The Initiative includes an industry-outreach component in which the Patent Office pledges to solicit industry input, convene a roundtable forum, and establish a formal customer partnership with the software, Internet, and electronic commerce industries regarding business method patents. ${ }^{152}$

The Initiative also includes measures designed to improve patent quality. The Patent Office has committed to provide enhanced technical training for examiners, with particular emphasis upon practices in banking, finance, electronic commerce, insurance, and Internet infrastructure. ${ }^{153}$ The Patent Office will also mandate a more strict prior art search for business method patent applications, including the requirement that examiners review specified secondary literature. ${ }^{154}$ The Initiative also provides for second-level review of all business method patent applications that have been preliminarily approved. ${ }^{155}$ Finally, the Patent Office will gauge its progress by placing additional business method patent applications before its quality-review personnel. ${ }^{156}$

The responsiveness of Patent Office management to business method patent quality problems is commendable. Whether the Initiative will result in improved electronic commerce patents remains to be seen, however. If pertinent prior art is not accessible to examiners, either because the Patent Office has not gathered the reference or because it has not been journalized, then expanded searching will be pointless. ${ }^{157}$ The Patent Office also possesses finite resources. Heightened Patent Office review of one class of inventions will result in diminished oversight of other inventions for which patents are sought. ${ }^{158}$

150. See U.S. Patent Trademark Office, Under Secretary of Commerce for Intellectual Property Dickinson Unveils New Initiative Focusing on Business Methods Patents, at http://www.uspto.gov/web /offices/com/speeches/00-22.htm (Mar. 30, 2000) (on file with the University of Illinois Law Review); see also Geneva Sapp, Net Patents Process Receives an Overhaul, INFOwORLD, Apr. 13, 2000, at 8.

151. U.S. Patent Trademark Office, supra note 150.

152. See id.

153. See U.S. Patent Trademark Office, Business Methods Patent Initiative: An Action Plan, at http://www.uspto.gov/web/offices/com/sol/actionplan.html (Aug. 21, 2000) (on file with the University of Illinois Law Review).

154. Id.

155. Id.

156. Id.

157. See supra note 91 and accompanying text.

158. See Victoria Slind-Flor, Business Patents Get $2 d$ Look: But Critics Assert That PTO's New Policies Won't Solve Problems, 22 NAT'L L.J., Apr. 17, 2000, at B6. 
Stepping beyond the Initiative, commentators have urged additional investments in patent quality. Among the more frequently mentioned proposals call for the hiring of additional examiners and, by raising salaries, retention of experienced examiners. ${ }^{159}$ These proposals tend toward the impractical given the financial distress in which the Patent Office finds itself. A further difficulty is that despite its current budgetary malaise, the Patent Office has already engaged in aggressive hiring efforts. In fiscal year 1998, the Patent Office hired 728 examiners, followed by the hiring of an additional 801 examiners in 1999. 160 The majority of the novice examiners were assigned to examine electrical and computerrelated inventions. ${ }^{161}$

The result of these extraordinary hiring efforts is that the group of examiners most likely to encounter business method patent applications possesses only modest experience. At least in the short term, the impact of this employment campaign upon patent quality will likely have been negative. The burden of training and supervising so many new hires may have detracted from examination efforts at a time when so many new disciplines have come under the wing of the patent law.

The severe shortage of individuals with high technology skills in the domestic workforce suggests that the Patent Office will not be able to maintain this pace. One industry association estimates that U.S. companies would fill less than half of their 1.6 million job vacancies involving technical skills during the 2000 calendar year. ${ }^{162}$ The Microsoft Corporation alone possessed sufficient job openings during the 2000 calendar year to hire the entire corps of 3200 Patent Office examiners. ${ }^{163}$ Unfortunately, the mere authorization of additional examiner positions does not mean that qualified individuals will be available to fill these posts, or that the Patent Office will be able to train them without diminishing its own search and examination capabilities.

Other commentators have called for changes in the examiner docket management system. Patent Office management tracks examiner workloads by crediting either a first action on the merits or a disposal of the application. Disposal counts are generally awarded either for the allowance or abandonment of the application. ${ }^{164}$ Noticeably absent from the list of ways to obtain a disposal count is continued rejection of the application. Additionally, Patent Office practice requires that examiners articulate their reasons for a rejection, while most often examiners need say nothing if they chose to allow a case. The belief is widely held that

159. See Mark A. Lemley, Reconceiving Patents in the Age of Venture Capital, 4 J. SMALL \& EMERGING BUS. L. 137, 147 (2000); Merges, supra note 5, at 606-07.

160. See Kisliuk \& Marshall, supra note 72, at 18.

161. See id.

162. See Marc Ballon, U.S. High-Tech Jobs Going Abroad, L.A. Times, Apr. 24, 2000, at C1.

163. See id.

164. E.g., MANUAL OF PATENT ExAMINING, supra note 80, $\$ 711.04(\mathrm{a})-(\mathrm{c})$, at 700-104 to 700-105. 
this regime encourages examiners to allow rather than to reject applications. ${ }^{165}$

Although this point is well taken, a review of earlier Patent Office management practices suggests that other possible methodologies have worked even less well. The current disposition point system actually arose from earlier regimes that awarded disposal points to examiners based merely upon the drafting of an Office Action. A common criticism of this system was that examiners were loathe to be rid of a particular application once they had taken the time to understand the technology and the claimed subject matter. Piecemeal rejections, elongated prosecutions and so-called submarine patents were the typical result. ${ }^{166}$ The current system marks an effort to bring closure to prosecution in a more timely fashion.

Perhaps the current disposal count system has been all too successful, but the details of examiner docket management may have only a secondary impact upon allowance rates at the Patent Office. Longestablished practice places the burden of persuasion and initial burden of production upon examiners to generate rejections. ${ }^{167}$ Otherwise the application must be allowed. The alternative possibility, requiring that applicants argue unknown and possibly unknowable objections to the patent, seems both unworkable and contrary to the Patent Act. ${ }^{168}$ Disposal point specifics may not loom particularly large in the face of an institutional framework that defaults towards allowance of a patent application.

Another possibility is that the Patent Office should devote more examination resources to those patent applications that claim commercially valuable inventions. The task of identifying the marketplace worth of innovations appears quite difficult to achieve in practice. ${ }^{169}$ The invention that seems the most capable is not always the marketplace winner, ${ }^{170}$ and technological capabilities may change dramatically over the twentyyear patent term. The result is a longstanding Patent Office policy of conducting an equally comprehensive prior art search for each submitted application.

A final, persistent patent reform proposal calls for augmentation of the applicant duty of disclosure. ${ }^{171}$ Rule 56 currently calls for applicants

165. See Merges, supra note 5 , at 609 (referring to disposal counts as "bonus points").

166. Interview with Mr. Ronald J. Stern, President of the Patent Office Professional Association, in Arlington, Va. (June 29, 2000).

167. See In re Oetiker, 977 F.2d 1443, 1449 (Fed. Cir. 1992) (Plager, J., concurring).

168. See In re Epstein, 32 F.3d 1559, 1570 (Fed. Cir. 1994) (Plager, J., concurring); In re Oetiker, 977 F.2d at 1449 .

169. See Merges, supra note 5, at 596-97.

170. E.g., JAMES LARDNER, FAST ForwaRd: Hollywood, THE JAPANESE AND THE ONSLAUGHT OF THE VCR 304-11 (1987) (discussing how Sony's Betamax, although originally termed the "ultimate" consumer electronics product, lost in the marketplace to the VCR).

171. E.g., Donald S. Chisum, Best Mode Concealment and Inequitable Conduct in Patent Procurement: A Nutshell, a Review of Recent Federal Circuit Cases and a Plea for Reform, 13 SANTA Clara COMPUTER \& HIGH TECH. L.J. 277, 318-19 (1997). 
to disclose only relevant prior art of which they are aware. ${ }^{172}$ Many have found a mandated prior art search to be a straightforward way to solve patent quality problems. ${ }^{173}$ A principal difficulty with this proposal is that it would encourage applicants to submit the entirety of their search results. Rather than focusing attention on a handful of the most pertinent prior art, examiners would likely be overwhelmed with dozens of remote references. This sort of applicant sandbagging, already the subject of frequent complaints by examiners, seems most unlikely to improve patent quality. ${ }^{174}$

\section{B. The Patent Opposition Panacea}

The Business Methods Patent Initiative and related proposals appear unlikely to contribute meaningfully to the solution of our current patent quality problems. Perhaps sensing the weaknesses of these proposals, academic observers have increasingly encouraged private involvement in Patent Office proceedings. ${ }^{175}$ These proposals typically call for either the augmentation of existing reexamination proceedings or wholesale adoption of opposition hearings based upon a European model.

A feature of U.S. law since 1981, the reexamination statute allows any individual, including the patentee, a licensee, and even the Patent Office Director himself, to cite a prior art patent or printed publication to the Patent Office. If the Patent Office determines that this reference raises "a substantial new question of patentability" with respect to an issued patent, then it will essentially renew prosecution of the issued patent. ${ }^{176}$ Traditional reexamination proceedings are conducted in an accelerated fashion on an ex parte basis, while a newly minted inter partes reexamination allows the requestor to participate more fully in the proceedings through the submission of argument and filing of appeals. ${ }^{177} \mathrm{Ei}$ ther sort of reexamination may result in a certificate confirming the pat-

172. See supra notes $87-88,98$ and accompanying text.

173. See Brenda Sandburg, PTO's Destination: Silicon Valley, THE RECORder (San Francisco), June 29, 1999.

174. See supra notes $90-91$ and accompanying text.

175. Writings favoring the adoption of expanded reexaminations or oppositions have not been limited to permanent members of law faculties. E.g., N. Thane Bauz, Reanimating U.S. Reexamination: Recommendations for Change Based upon a Comparative Study of German Law, 27 CREIGHTON L. REv. 945 (1993); Shannon M. Casey, Recent Development, the Patent Reexamination Reform Act of 1994: A New Era of Third Party Participation, 2 J. INTELL. Prop. L. 559 (1995); Nancy J. Linck et al., A New Patent Examination Regime for a New Millennium, 35 Hous. L. REV. 305 (1998); Marvin Motsenbocker, Proposal to Change the Patent Reexamination Statute to Eliminate Unnecessary Litigation, 27 J. MARShALl L. REV. 887 (1994); Allan M. Soobert, Breaking New Grounds in Administrative Revocation of U.S. Patents: A Proposition for Opposition-and Beyond, 14 SANTA CLARA COMPUTER \& High TECH. L.J. 63 (1998).

176. Mark D. Janis, Inter Partes Patent Reexamination, 10 Fordham InTEll. Prop. Media \& ENT. L.J. 481, 487 (2000).

177. See id. (quoting the language used in 35 U.S.C.A. $\$ 312(\mathrm{a})$ (West Supp. 2000)). 
entability of the original claims, an amended patent with narrower claims or a declaration of patent invalidity. ${ }^{178}$

Congress intended reexamination to serve as an inexpensive alternative to judicial determinations of patent validity. ${ }^{179}$ The fees associated with reexamination are modest compared to patent litigation, which often runs into the millions of dollars. ${ }^{180}$ Reexamination also allows further access to Patent Office technical expertise when additional prior art is discovered after issuance. ${ }^{181}$

Reexamination presents a vitiated version of the opposition proceeding featured by many foreign patent systems. ${ }^{182}$ An opposition is a robust administrative revocation proceeding that may address a broad range of patentability issues. ${ }^{183}$ In further contrast to a reexamination, which is principally contested through written correspondence, the declaration of an opposition may lead to full adversarial hearings conducted at the patent office. ${ }^{184}$

Most opposition systems concern granted patents and are therefore termed post-grant oppositions. ${ }^{185}$ Post-grant oppositions must be filed in a timely fashion following patent issuance. ${ }^{186}$ Other systems have provided for pre-grant oppositions that may be filed against pending patent applications. ${ }^{187}$ Statistics seem to show that foreign oppositions are more widely employed and more often result in findings of patent invalidity than domestic reexaminations. ${ }^{188}$

Any follower of recent academic writings on patents must be struck by the unanimity of support for the introduction of an opposition regime into U.S. law. In a recent article, Professor Merges identified oppositions as "the ideal solution" to problems of the contemporary patent system. ${ }^{189}$ Professor Merges explained that the competitors of a patentee exhibit two virtues: they are the most interested individuals in the validity of the patent, and they tend to possess the most pertinent knowledge concern-

178. See id. at 484-85.

179. See Janis, supra note 8, at 36-38.

180. See Steven J. Elleman, Problems in Patent Litigation: Mandatory Mediation May Provide Settlements and Solutions, 12 OHIO ST. J. ON DiSP. RESOL. 759, 762-63 (1997).

181. See Wayne O. Stacy, Note, Reexamination Reality: How Courts Should Approach a Motion to Stay Litigation Pending the Outcome of Reexamination, 66 GEO. WASH. L. REV. 172, 174-75 (1997).

182. See AdelmAN ET AL., supra note 32, at 810; Symposium, Opposition Systems, 4 AM. INTELl. PROP. L. ASS'N Q.J. 92 (1976).

183. E.g., European Patent Convention, Art. 100, reprinted in The Draft European Patent CONVENTION: A COMMENTARY WITH ENGLISH AND FRENCH TEXTS (G. Oudemans ed., 1963).

184. E.g., EuROPEAN PATENT OFFICE, GuIDELINES FOR EXAMINATION IN THE EUROPEAN PATENT OFFICE, pt. E, ch. III (1981).

185. ADELMAN ET AL., supra note 32, at 810.

186. The European Patent Office accepts opposition filings within nine months from the date of the patent grant. See European Patent Convention, supra note 183, art. 99. In Germany oppositions must be filed within three months from the date the patent issues. See Ernst K. Pakuscher, Patent Procedures in the Federal Republic of Germany, 4 INT'L TAX \& BUS. LAW. 86, 94 (1986).

187. See ADELMAN ET AL., supra note 32, at 810.

188. See Merges, supra note 5, at 612-13.

189. Id. at 614 . 
ing the validity of the patent. ${ }^{190}$ According to Professor Merges, oppositions provide an optimal mechanism for stakeholders to disclose patent validity information as early as possible. ${ }^{191}$

Professor Dreyfuss has also spoken favorably upon the expansion of post-grant proceedings in the context of business method patents. In testimony before Congress, Professor Dreyfuss explained that the presumption of validity attached to an issued business method patent may be too weighty in light of Patent Office examination difficulties. ${ }^{192}$ Reflecting earlier work that reached a similar conclusion, ${ }^{193}$ she suggested that Congress adopt oppositions or expanded reexaminations in order to resolve business method patent quality problems. ${ }^{194}$

Professor Reichman has lent an international perspective to this discussion. Offering suggestions to developing nations that hope to balance treaty obligations with domestic development goals, he favors the limitation of proprietary interests held by distant, foreign owners. According to Professor Reichman, oppositions are a "uniformly advisable" mechanism for nations with nascent patent systems to curb issued patents. ${ }^{195}$

Professor Janis too has urged the adoption of a robust administrative patent revocation system. ${ }^{196}$ Relying upon a thorough historical and comparative analysis, Professor Janis found reexamination inappropriately oriented towards the correction of invalid patents. Instead, he suggested that the patent law offer a valid alternative to litigation by means of an opposition. Professor Janis proposed that oppositions involve liberal standing requirements, broad substantive scope and use of an expert panel. ${ }^{197}$

Enriched by both economic insights and empirical research, Professor Nard has also argued in favor of oppositions. ${ }^{198}$ According to Professor Nard, the interests of patentee, competitor, and the public alike favor certainty in the allocation of proprietary rights. ${ }^{199}$ Only when patent rights are known with some confidence will individuals go about improving upon and inventing around the patented invention. Professor Nard

190. See id. at 615

191. See id.

192. Before Subcomm. on Courts and Intellectual Property of House Comm. on Judiciary, 106th Cong. (Mar. 9, 2000) (statement of Rochelle Cooper Dreyfuss, Professor of Law, New York University School of Law), available at 2000 WL 282803.

193. See id.

194. Before Subcomm. on Courts and Intellectual Property of House Comm. on Judiciary, 106th Cong. (Mar. 9, 2000) (statement of Rochelle Cooper Dreyfuss, Professor of Law, New York University School of Law), available at 2000 WL 282803.

195. Reichman, supra note 8, at 31.

196. See Janis, supra note 8, at 118-22.

197. See id. at 118 .

198. See Nard, supra note 8, at 759 .

199. See id. at 759-60. 
explained that oppositions further this goal by promoting proprietary and competitive certainty ex ante. ${ }^{200}$

Professor Nard further revealed a favorable posture towards oppositions among the judiciary. His survey of federal district court judges showed that a plurality favored the implementation of a post-grant opposition proceeding. ${ }^{201}$ Industry observers and members of the bar appear of like mind. Representative is Amazon.com's Jeff Bezos, who suggested that the Patent Office provide for pre-grant oppositions prior to the issuance of a business method or software patent. ${ }^{202}$ The two major societies of intellectual property professionals, the American Intellectual Property Law Association and American Bar Association's Section on Intellectual Property Law, have also adopted resolutions supporting oppositions. ${ }^{203}$

Although each of these sources contained its own thoughtful analysis, they shared the central assertion that we can solve our patent quality problems by designing an efficient and inexpensive opposition proceeding. Once streamlined revocation procedures are set into place, we are told, private parties will be stimulated to bring the most pertinent prior art references to the attention of the Patent Office. The result will be better informed decision making, improved patent quality, and a restored patent system.

The conventional wisdom may soon leave its mark on U.S. patent law. On October 3, 2000, the Honorable Howard Berman introduced H.R. 5364 on the floor of the House of Representatives. ${ }^{204}$ Entitled the Business Method Patent Improvement Act of 2000, H.R. 5364 would for the first time introduce oppositions into the U.S. patent law. ${ }^{205}$ Although this legislation limits oppositions to patent applications claiming business methods, the grounds for opposition essentially include all substantive bases for patentability. ${ }^{206}$

The general acknowledgment of the wisdom of oppositions is striking. Perhaps even more conspicuous, however, is the persistence of such proposals in the face of considerable experience suggesting that they will be of little consequence in the United States. A post-grant opposition is at bottom a more robust version of the reexamination, which stands as one of the greatest failures of the modern patent system. ${ }^{207}$ In 1981 , a time when far fewer patent applications were filed and issued than today, forecasters predicted the filing of as many as 3000 reexamination requests per annum. In 1996, so far the banner year for the filing of reex-

200. See id. at 795 .

201. See id. at 796-800.

202. See Bezos, supra note 148 .

203. See Nard, supra note 8 , at 764 n.28.

204. H.R. 5364, 106th Cong., (introduced by the Honorable Howard Berman on Oct. 3, 2000).

205. See id. §3.

206. See id.

207. See Janis, supra note 8 , at 93. 
amination requests, a grand total of 418 were filed. ${ }^{208}$ The newly minted inter partes reexamination may prove even less popular, with commentators predicting that industry will make scant use of these proceedings. ${ }^{209}$

Pre-grant oppositions also lack a firm footing. Pressures from U.S. industry were a key factor prompting the Japanese government to abolish pre-grant oppositions. ${ }^{210}$ Domestically, the U.S. patent system still includes two mechanisms for challenging pending patent applications, each of which is used only rarely. The nearest analogy to a pre-grant opposition here, protests, allow individuals to submit prior art to the Patent Office. The protestor must specifically identify the application and offer a concise explanation of each submitted reference. ${ }^{211}$

The Patent Office may also conduct public use proceedings against a pending patent application. ${ }^{212}$ Patent Office regulations allow individuals to submit affidavits and other evidence showing that the invention was on sale or in public use within the terms of $\S 102$. If this evidence results in a prima facie case, the Patent Office may conduct hearings to determine whether this use or sales activity amounts to prior art. Such a hearing may result in the submission of evidence and hearing of witnesses. Like protests, the Patent Office need convene public use proceedings only on an infrequent basis. ${ }^{213}$

Aware of the reluctance of potential patent opponents to employ reexaminations, protests, and public use proceedings, proponents of oppositions often point to perceived deficiencies in these procedures. Under this view, potential patent opponents are so discouraged by the inadequacies of current proceedings that they simply fail to step forward at all. These arguments are not without merit, for no Patent Office procedure does or likely could substitute for judicial proceedings. Closer inspection suggests, however, that the noted procedural deficiencies do not fully explain the reticence of potential patent opponents.

For example, commentators have turned to the traditional requirement that the Patent Office maintain applications in confidence as the reason that protests and public use proceedings are so infrequently employed. Observers have often suggested that individuals have simply been unaware of the patent applications filed by their competitors, and therefore simply have been unable to commence a protest or public use proceeding. ${ }^{214}$ This explanation rings rather hollow, however, for savvy competitors can often determine the contents of a domestic patent application by consulting a foreign counterpart. If an inventor seeks patent

208. Merges, supra note 5, at 610 .

209. See Janis, supra note 176 , at $498-99$

210. See Janis, supra note 8, at 116-17.

211. See National Processing Provisions, Protests and Public Use Proceedings, 37 C.F.R. § 1.291(b) (2000).

212. See id. §1.292(a).

213. See Nard, supra note 8 , at 764 n.27.

214. See Janis, supra note 8, at 16; see also Nard, supra note 8, at 764 n.27. 
protection both in a foreign country and the United States, the patent application will be published overseas eighteen months following the earliest filing date. Competitors have the opportunity to inspect the foreign application and either see for themselves, or take a considerably educated guess at, the content of the U.S. application. At this point they could readily commence a protest or public use proceeding, but experience shows that they rarely do.

Observers have also pointed to the restrictions placed upon the reexamination proceeding as compared to litigation. The Patent Act allows a reexamination to be provoked solely due to prior art patents and printed publications that were not before the Patent Office during the original proceeding. ${ }^{215}$ Yet, as a practical matter, patents and printed publications remain the most accessible prior art for a would-be patent opponent. ${ }^{216}$ Further, the Federal Circuit has taken an expansive view of reexamination, at least once the reexamination has been properly declared. Exemplary is In re Lonardo ${ }^{217}$ where the court held that double patenting was appropriately taken during reexamination. Given that double patenting rejections do not in any way concern the prior art, reexamination may not be so limited as it initially appears.

Another prominent criticism was that third parties play only a limited role in traditional ex parte reexaminations. ${ }^{218}$ Congress responded by enacting an inter partes reexamination with an expanded role for the third party requester. ${ }^{219}$ Observers have again predicted that industry will not make much use of inter partes reexaminations, however. Concerned that inter partes examinations would be subject to abuse, Congress mandated that an inter partes reexamination participant could not further challenge the reexamined patent based upon prior art that was, or should have been, before the PTO. ${ }^{220}$ According to critics, this preclusive effect associated with inter partes reexaminations will severely chill their use. ${ }^{221}$

If these accounts are to be believed, then the stewards of our patent system have suffered an incredible string of misfortunes. The entire menu of domestic patent challenges, including protests, public use proceedings, two varieties of reexaminations, and declaratory judgments includes not a single vehicle capable of animating would-be patent protestors. Each sort of revocation procedure instead includes a unique, readily identifiable defect that almost wholly suppresses potential users. This view naturally leads to the conclusion that a more robust opposition exists in the European mode. Statistics seem to support this conclusion,

215. See 35 U.S.C. $\$ 301$ (1994); see also id. \$ 302.

216. See id. \$102(a); see also supra text accompanying note 62.

217. See 119 F.3d 960, 968 (Fed. Cir. 1997).

218. See Janis, supra note 8, at 69-71.

219. See Janis, supra note 176, at 482.

220. See id. at 494.

221. See id. at 492-98. 
for they show that oppositions are subject to considerable greater use than the more limited proceedings extant in the United States. ${ }^{222}$

European Patent Office oppositions have attracted their own share of critics, however. The number of contestable issues is limited in $\mathrm{Mu}$ nich as well. ${ }^{223}$ A lax procedural setting and concern over the impartiality of the adjudicators have also raised concerns. ${ }^{224}$ European oppositions have been the subject of abuses and delaying tactics. ${ }^{225}$ For example, the inventors of the well-known Oncomouse filed a European patent application in 1985. ${ }^{226}$ Years later, the patent remains the subject of seventeen oppositions filed by animal rights activists, environmentalists, and other groups. ${ }^{227}$

More significantly, higher European usage rates lack meaning within the context of the U.S. patent system. In Continental patent systems, an accused patent infringer may not assert an invalidity defense during enforcement litigation. ${ }^{228}$ Invalidity arguments may only be heard within an opposition or, once the deadline for an opposition has passed, a distinct nullity proceeding. ${ }^{229}$ Of course, where oppositions provide the principal mechanism for challenging patent validity, higher usage rates are inevitable.

Critics of the various domestic proceedings for disputing issued patents offer many valid points. Yet the unpopularity of each of the prevailing mechanisms for challenging U.S. patents is telling. We should recognize the possibility that these low usage rates have resulted not from a series of particularized defects, but from more fundamental forces. Competitors of a patentee have been presumed to possess incentives to contest issued patents, but experience suggests that they often lack motivation to take up a patent challenge of any stripe. A simpler, more persuasive explanation for this behavior results from a more thorough consideration of whether private citizens possess incentives to clear the rolls of invalid patents to act in the public interest. This article next constructs this account and considers its ramifications for postindustrial patent reform.

222. See Merges, supra note 5, at 612-14.

223. See Convention on the Grant of European Patents, Oct. 5, 1973, 13 I.L.M. 270; see also EUROPEAN PATENT OFFICE, supra note 184 , pt. D, ch. III, If 5, available at http://www.europeanpatent-office.org/legal/gui_/mesle/d_iii_5.htm (last updated July 27, 2000) ("The following allegations, for example, do not constitute grounds for opposition: that national rights of earlier date exist ... that the proprietor of the patent is not entitled to the European patent, that the subject-matter of the patent lacks unity, [and] that the claims are not supported by the description ....").

224. See Paul A. Coletti, No Relief in Sight: Difficulties in Obtaining Judgments in Europe Using EPO Issued Patents, 81 J. PAT. \& TRADEMARK OFF. SOC'Y 351, 367-68 (1999).

225. See id. at 354-57.

226. See Simon Cohen, Focus: Intellectual Property: Unravelling Code of Genetic Patents, THE LAw., Sept. 29, 1998, available at 1998 WL 9168306.

227. See id.; European Oncomouse Patent Opposed, 5 J. ProprietaRy RTs., Mar. 1993, at 45.

228. See Janis, supra note 8, at 109-10.

229. See id. 


\section{Reexamining Patent Opposition Proceedings}

The patent law is often said to solve a problem of collective action. We suspect that inventions, like other public goods, will be underproduced relative to social need. Society as a whole values inventions, but individuals lack private incentives to produce them due to their nonexclusive and nonrival traits. The patent system changes the rules of this production game by reducing the public goods characteristics of inventions. The aim is to solve this market problem and stimulate the production of inventions. ${ }^{230}$

These familiar teachings hold explanatory power in the context of patent challenges as well. A central point of this article is that a challenge to patent validity should also be recognized as involving collective action problems. By viewing patent challenges in this familiar light, we can both account for the sporadic use of reexaminations, protests, and public use proceedings, and recognize that the adoption of oppositions is unlikely to solve our current patent quality problems. Our principal task should not be to remove procedural obstacles for would-be patent challengers, but to encourage individuals to oppose invalid patents in the first place.

This analysis begins by recognizing that patent validity challenges exhibit the characteristics of public goods. First, invalidated patents convey benefits that are nonrival. ${ }^{231}$ The disclosure of an invalidated patent is ordinarily injected into the public domain. Like other sorts of information, the invention may be freely used by all without detracting from the benefits of any. The potential benefits of a successful patent opposition are also nonexcludable. ${ }^{232}$ Patents are declared invalid for all purposes, not vis-à-vis a particular individual. A prevailing opponent of a patent therefore cannot prevent others from practicing the invention claimed in the invalidated patent. Others may readily free ride from the efforts of the former patentee and the opponent, employing the teachings of the invalidated patent to practice the invention without compensation to anyone.

Although this result may seem intuitive, the nonexcludability of a successful charge of patent invalidity is a relatively recent development. As reflected by the 1936 Supreme Court decision in Triplett $v$. Lowell, ${ }^{233}$ for many years an earlier declaration of patent invalidity did not prevent a patentee from filing infringement charges against a different defendant. Although criticized as relying upon the outmoded principle of mutuality of estoppel, the Triplett rule possessed the virtue of encouraging geographically dispersed individuals to mount their own patent challenges.

230. See supra notes $131-36$ and accompanying text.

231. See supra notes 131-36 and accompanying text.

232. See supra notes 131-36 and accompanying text.

233. 297 U.S. $638(1936)$ 
Other courts might find an earlier holding of invalidity persuasive, of course, but they were not bound by it. Secure that they alone would benefit from a favorable judgment, potential opponents of a patent were encouraged to take action.

The Tripplet rule is no longer with us, for the Court's subsequent decision in Blonder-Tongue Laboratories, Inc. $v$. University of Illinois Foundation overturned that case. ${ }^{234}$ Citing the public interest in efficient judicial administration and achieving a settled result on patent validity, the Court held that patentees were estopped from asserting patents that had been held invalid, even where another defendant had been the prevailing party. Blonder-Tongue has attracted few critics over the years, but among its drawbacks is that a potential opponent cannot appropriate the benefits of a successful charge of patent invalidity to itself. In economic terms, the benefits of a successful charge of patent invalidity became nonexcludable.

The identification of patent challenges as yielding benefits that are nonrival and nonexcludable brings certain insights. We can expect that patent challenges will be subject to collective action problems. The resulting consumptive externalities should result in fewer patent challenges than are socially optimal, a recognition supported by our experience. The scant use of reexamination, protests, and public use proceedings indicates that industry actors have not been sufficiently animated into challenging patents that should be brought down. ${ }^{235}$

The recent episode involving the so-called $\mathrm{Y} 2 \mathrm{~K}$ windowing patent displays the depths of this collective action problem. In 1996, the Patent Office granted a patent on the use of so-called windowing techniques to solve computer errors associated with the close of the twentieth century. ${ }^{236}$ During November 1999, its proprietor, Bruce Dickens, sent hundreds of letters to leading companies with requests for royalty payments. ${ }^{237}$ The result was an industry uproar that made its way to the lay press. $^{238}$ Commentators opined that the patent claimed technology that would have been obvious in light of techniques well known to the field of computer science. ${ }^{239}$

On December 21, 1999, a reexamination was provoked for the Y2K windowing patent. The defender of the public interest did not arise from the ranks of private industry, however, for the reexamination was sought

234. 402 U.S. 313 (1971).

235. See supra note 218 and accompanying text.

236. U.S. Patent No. 5,630,118 (issued May 13, 1997).

237. Dugie Standeford, PTO Orders Reexamination of Y2K Fix Patent, 222 THE LEGAL INTELLIGENCER, Jan. 7, 2000, at 4.

238. E.g., William Cray, Patented Y2K Fix in Review, The Plain Dealer (Cleveland), Dec. 24, 1999, at 3C; P.J. Huffstutter, Tech Beat: He Says He Patented a Y2K Cure, but Big Companies Aren't So Sure, L.A. TImes, Jan. 17, 2000, at C1; Teresa Riordan, Y2K Quick-Fix Patent to Get Further Scrutiny, THE MilwaUkeE Journal SENTINEL, Dec. 28, 1999, at 4.

239. See Kevin Coughlin, Technology Upends the Meaning of Invention: Patent Requests Shift to Ideas, Know-How, STAR-LEDGER (Newark), Mar. 12, 2000, available at 2000 WL 15869531. 
by the Patent and Trademark Office Commissioner himself. ${ }^{240}$ Amazingly, despite the extraordinary publicity and singular sense of industrial alarm, no individual, enterprise, or foundation led the charge to contest the Y2K windowing patent. The motivation of the Patent Office appeared not so much as safeguarding the public, but shielding itself from ridicule resulting from its issuance of a plainly invalid patent. ${ }^{241}$

Other Commissioner-requested reexaminations have followed a similar pattern. ${ }^{242}$ The central lesson from these experiences is that, as in other contexts, industrial actors often prefer to shirk than work. In addition to explaining current industry disinterest in disputing issued patents, this account holds a normative component. Opposition procedures now seem quite unlikely to stimulate private citizens to become champions of the public interest. Oppositions offer procedural conveniences, but they do not encourage patent challenges in the first place. The poverty of opposition proposals suggests that other approaches may present more vital solutions to our patent quality problems.

Recognition of the collective action problems inherent in patent challenges brings another insight from the economic literature. Patent challenges also appear laden with problems of collusion. The holder of patent-defeating prior art has two basic options: mount a validity challenge, or hold the reference in the hope of dealing with the patentee. The latter possibility might often be the more attractive one. Upon encountering an infringement charge, the competitor can privately disclose the prior art reference to the patentee. So long as sufficient supracompetitive profits exist to go around, the patentee ordinarily possesses incentives to suppress the prior art by means of a favorable license. Both parties may then extract information rents from the consuming public by maintaining artificially high prices due to an invalid patent. ${ }^{243}$

This analysis may strike some readers as both speculative and rather cynical. Still, patentees from George Selden to Jerome Lemelson have long recognized that prospective licensees often prefer to pay a modest royalty rather than contest an invalid patent. ${ }^{244}$ The prospect of collusion has also received a thorough airing in the context of licensee estoppel. Casting doubt on the Supreme Court's view that licensees "may often be the only individuals with enough economic incentive to challenge the patentability of an inventor's discovery," 245 Professor Dreyfuss has explained that the interests of patent licensees are often aligned with the

240. See Standeford, supra note 237 , at 4.

241. See ADELMAN ET AL., supra note 32, at 808.

242. See Terri Suzette Hughes, Comment, Patent Reexamination and the PTO: Compton's Patent Invalidated at the Commissioner's Request, 14 J. MARSHALL J. COMPUTER \& INFO. L. 379 (1996).

243. See Note, An Economic Analysis of Royalty Terms in Patent Licenses, 67 MINN. L. REV. 1198 (1983).

244. See Steve Blount, The Use of Delaying Tactics to Obtain Submarine Patents and Amend Around a Patent That a Competitor Has Designed Around, 81 J. PAT. \& TradeMARK OFF. SOC'Y 11, 13-14, 19-24 (1999); see also Painton \& Co. v. Bourns, Inc., 442 F.2d 216, 225 (2d Cir. 1971).

245. Lear, Inc. v. Adkins, 395 U.S. 653, 670 (1969). 
patent owner in seeking to maintain the validity of the patent. ${ }^{246}$ A licensee's successful patent challenge may only invite competition, with the prospect of increased production and diminished profitability. Expanding upon the observation of Professor Dreyfuss, we need only appreciate that any holder of patent-defeating prior art is a potential licensee.

Two additional episodes suggest that concerns over collusion are legitimate. The first of these concern administrative proceedings termed "interferences." The Patent Office conducts interferences in order to determine which of a set of competing individuals was the first inventor. ${ }^{247}$ The Patent Act calls for only the first person to invent the subject matter of the interference to obtain the patent. ${ }^{248}$ The other parties to the interference potentially become infringers. ${ }^{249}$

The Patent Office has recognized that the parties to an interference may possess incentives to enter into collusive agreements sharing patent rights. ${ }^{250}$ For example, the interfering applicants may discover prior art that would defeat the patent no matter which party is adjudicated the first inventor. Rather than expose an invalid patent, the parties to the interference may instead settle their dispute and enter into a licensing arrangement. $^{251}$ To ferret out such abuses, the Patent Act requires that copies of private agreements settling interferences be made available for public inspection. ${ }^{252}$

A second example originates from the complex provisions of the Hatch-Waxman Act. The Hatch-Waxman Act governs the relationship between innovative pharmaceutical companies and their generic competitors. Among its provisions is an incentive for generic drug manufacturers to challenge patents held by innovative pharmaceutical companies. The Act posts a reward to the first generic manufacturer to contest a drug patent. If that patent is struck down, the Food and Drug Administration may only grant marketing rights to the first generic challenger for a 180-day period. ${ }^{253}$ The intended effect of the Hatch-Waxman Act was to provide to the successful generic manufacturer, in the words of the Court of Appeals for the D.C. Circuit, an "Edenic moment of freedom" from competition. ${ }^{254}$

246. See Dreyfuss, supra note 8

247. See 35 U.S.C. § 135(a) (1994).

248. See id.

249. Assuming that the losing party to the interference itself makes, uses, sells, offers to sell, or imports into the United States the patented invention. See 35 U.S.C. \& 271(a). For a discussion of interference proceedings, see Kevin McMahon, Patent Interferences: A Snare for the Unwary or a Neglected Weapon?, 4 J. ProprieTARY RTS., June 1992, at 20.

250. See Matthew B. Zisk, Mediation and Settlement of Patent Disputes in the Shadow of the Public Interest, 14 OHIO ST. J. DisP. RESOLUTION 481, 501-03 (1999).

251. See id.

252. See 35 U.S.C. § 135(c); 37 C.F.R. § 1.666 (1999).

253. See Elizabeth H. Dickinson, FDA's Role in Making Exclusivity Determinations, 54 FoOD \& DRUG L.J. 195, 198-200 (1999).

254. Mova Pharm. Corp. v. Shalala, 140 F.3d 1060, 1064 (D.C. Cir. 1998). 
Instead of encouraging patent challenges and increasing public accessibility to generic drugs, however, experience shows that the 180-day exclusivity provision has tended to promote collusive activity between the patentee and first challenger. Although the Hatch-Waxman Act calls for a reward to the initial patent opponent, the statute does not require that the original challenger actually pursue the matter to final judgment. In practice, the more likely result is that the two parties enter into a cash settlement that can run into the millions of dollars. ${ }^{255}$

With the first patent opponent allied with the patentee, the HatchWaxman Act leads to the unusual result of discouraging further patent challenges. Even if a subsequent challenger manages to invalidate the patent during litigation, 180 days must pass before the FDA may grant the victorious party permission to market the drug. Further, the tardy challenger itself obtains no market exclusivity. As individuals seldom possess incentives to act as champions for the entire generic pharmaceutical industry, Hatch-Waxman Act procedures have tended to bar rather than promote the availability of generic drugs. ${ }^{256}$

This experience with interferences and the Hatch-Waxman Act should promote a more general wariness of collusive behavior between patentees and potential patent challengers. One need not have mastered the political economy of patent challenges to sense that private dealing often presents a more attractive option than disputing a patent grant. Opposition proposals do nothing to alter this fundamental set of incentives, leaving little reason to suspect that they will somehow invigorate the active pruning of invalid patents from the public rolls.

Problems of collusion and collective action potentially apply to any sort of patent. In the area where patent quality problems seem most acute, business methods, the incentives to challenge patents are even further diminished. Among the titles of the American Inventors Protection Act of 1999 is the First Inventor Defense Act, which creates a personal infringement defense for a prior inventor of a business method that is later patented by another. ${ }^{257}$ By providing those enterprises best able to mount a successful patent challenge with a more attractive option, Congress has dealt another setback to the public interest in eliminating invalid patents.

255. One recent incident involved the antihyperintensive drug Hytrin. In early 1998 , the patentee, Abbott Laboratories, agreed to pay two potential competitors a total of $\$ 6.5$ million per month in exchange for their promise not to produce a generic version of Hytrin. The parties cancelled their deals upon facing an investigation from the competition authorities. Hytrin's generic equivalent, terazosin, at last made its market debut in August 1999. Similar arrangements have been documented with respect to such patented drugs as tamoxifen, Cardizem CD, K-DUr, Cipro, and diltiazem. See Engelberg, supra note 132, at 416-18; see also Sheryl Gay Stolberg \& Jeff Gerth, Deals to Keep Generic Drugs Off Market Under Scrutiny: Pharmaceutical Firms Have Become Aggressive About Fending Off Competition as Drug Patents Expire, The OREGoniAn, July 23, 2000, at A05.

256. Engelberg, supra note 132, at 422-25.

257. First Inventor Defense Act of 1999, Pub. L. No. 106-113, § 4302, 113 Stat. 1536 (codified as amended at 35 U.S.C.A. $\S 273$ (West 2000)). 
The impetus for First Inventor Defense Act bears a brief explanation. ${ }^{258}$ This statute reflects the complex relationship between the law of trade secrets and the patent system. Trade secrecy protects individuals from misappropriation of valuable information that is useful in commerce. Individuals might maintain an invention as a trade secret due to ignorance of the patent system, or because they are unable to bear costly patent acquisition expenses. Inventors might also believe they can keep their invention as a secret longer than the period of exclusivity granted through the patent system. . $^{259}$

Although many individuals opt to maintain their inventions as trade secrets, the patent system has not favored them. ${ }^{260}$ Well-established patent law provides that an inventor who makes a secret, commercial use of an invention for more than one year prior to filing a patent application at the PTO forfeits his own right to a patent. ${ }^{261}$ This policy is principally based upon the desire to maintain the integrity of the statutory proscribed patent term. The patent law grants patents a term of twenty years, commencing from the date a patent application is filed. ${ }^{262}$ If the trade secret holder could make commercial use of an invention for many years before choosing to file a patent application, he could disrupt this regime by delaying the expiration date of his patent.

On the other hand, settled patent law principles established that prior secret uses would not defeat the patents of later inventors. ${ }^{263}$ If an earlier inventor made secret commercial use of an invention, and another person independently invented the same technology later and obtained patent protection, then the trade secret holder could face liability for patent infringement. This policy was based upon the reasoning that issued, published patent instruments fully inform the public about the invention, while trade secrets do not. As between a subsequent inventor who patented the invention, and thus had disclosed the invention to the public, and an earlier trade secret holder who had not, the law favored the patent holder.

The sudden patentability of methods of doing business has focused attention upon the relationship between patents and trade secrets. Inventors of methods of doing business traditionally relied upon trade secret protection because such inventions had long been regarded as unpatentable subject matter. As a result, inventors of innovative business methods obtained legal advice not to file applications at the PTO on

258. See generally James R. Barney, The Prior User Defense: A Reprieve for Trade Secret Owners or a Disaster for the Patent Law?, 82 J. PAT. \& TRAdEMARK OFF. SOC'Y 261 (2000) (critiquing the First Inventor Defense Act of 1999).

259. David D. Friedman et al., Some Economics of Trade Secret Law, 5 J. Econ. PerSP. 61, 63 (1991).

260. See Joan E. Schaffner, Patent Preemption Unlocked, 1995 WIS. L. REV. 1081, 1120-22.

261. See Metallizing Eng'g, Co. v. Kenyon Bearing \& Auto Parts, Co., 153 F.2d 516, 518 (1946).

262. See 35 U.S.C. $\$ 154(\mathrm{a})(2)$ (1994).

263. See W.L. Gore \& Assocs. v. Garlock, Inc., 721 F.2d 1540, 1550 (Fed. Cir. 1983). 
their inventions. This advice was sound under the patent law as it then stood.

By altering this traditional principle, State Street Bank was perceived as harming earlier inventors of business methods. Many of these inventors had maintained their innovative business methods as trade secrets for many years. As a result, they were unable belatedly to obtain patent protection on their business methods. As well, because trade secrets did not constitute prior art against the patent applications of others, a subsequent inventor would be able to obtain patent protection. Under these circumstances, a trade secret holder could find himself an adjudicated infringer of a patented business method that he actually invented first. ${ }^{264}$

The First Inventor Defense Act reconciles these principles by providing an infringement defense for an earlier inventor of a method of doing business that was later patented by another. This infringement defense is personal to a previous inventor and is subject to several qualifications. ${ }^{265}$ First, the defendant must have reduced the infringing subject matter to practice at least one year before the effective filing date of the application. ${ }^{266}$ Second, the defendant must have commercially used the infringing subject matter prior to the effective filing date of the patent. ${ }^{267}$ Finally, any reduction to practice or use must have been made in good faith, ${ }^{268}$ without derivation from the patentee or persons in privity with the patentee. ${ }^{269}$.

The First Inventor Defense Act expressly states that patents shall not be held invalid under section 102 or 103 because the first inventor defense is raised or established. ${ }^{270}$ Many entities that qualify for the first inventor defense have likely engaged in patent-defeating acts as well, however. As a result, accused infringers who previously would have raised invalidity defenses may now opt to assert the first inventor defense instead. It is easy to imagine circumstances when they will chose the latter, thereby retaining an invalid patent on the books at the expense of their competitors.

Suppose, for example, that the Sigil Bank and Trust Company reduced to practice an innovative method of managing an investment portfolio on December 27, 1997. Sigil maintained its method as a trade secret and put it into commercial use as of October 12, 1999. Sigil later learned that one of its employees had disclosed the invention in a letter sent to several individual investors on January 19, 1999. Sigil disciplined the employee but remained confident that the recipients of the letters would not perceive the value of the invention.

264. See Thomas, supra, note 6 , at 32 n.156.

265. See 35 U.S.C.A. \& 273(b)(6) (West Supp. 2000).

266. See id. $\S 273(\mathrm{~b})(1)$.

267. See id.

268. See id.

269. See id. $\$ 273(\mathrm{~b})(3)(\mathrm{B})$.

270. See id. \$273(b)(9). 
Subsequently, an independent inventor named Jack Chalker independently conceived of the same business method. Chalker filed a patent application on June 1,2000, disclosing and claiming the identical method of managing of an investment portfolio. The patent issued on November 1, 2001, at which time Chalker filed an infringement suit against Sigil.

Prior to the First Inventor Defense Act, Sigil would likely contend that the Chalker patent was invalid due to the errant employee letters. Provided that the letters provide an enabling disclosure of the patented business method, they should prove patent defeating. ${ }^{271}$ Today, Sigil would find assertion of the first inventor defense more advantageous. Sigil would merely demonstrate its dates of reduction to practice and commercial use without necessarily disclosing its letters to the court. A core benefit of this tactic is that Sigil need not share the benefits of asserting the defense with others in the financial services industry. The first inventor defense is personal, ${ }^{272}$ and as Chalker does not himself practice the invention on a commercial scale Sigil need not be concerned with him. Indeed, Sigil may free ride off Chalker's exclusive rights, for each time Chalker enjoins or licenses another, Sigil gains competitive advantages in the industry. Of course, Sigil's competitors will not likely have access to the prior art upon which Sigil might have relied.

This example illustrates that with the First Inventor Defense Act in place, we can no longer assume that accused infringers of business method patents will apply pertinent knowledge towards an patent invalidity argument. A competitor of a patentee may well possess individual incentives to assert the first inventor defense instead. Each time an accused infringer asserts the first inventor defense in this manner, the public interest of striking down invalid patents is defeated. Coupled with the problems of collective action and collusion, the first inventor defense provides another basis for concern over the integrity of the patent system in the field of business methods.

\section{A Proposal For PATENT Bounties}

Recognition that patent challenges present problems of collective action reveals that oppositions are unlikely to solve patent quality problems. Economic theory, experience, and analysis of the First Inventor Defense Act alike demonstrate that, opposition or not, private parties are insufficiently disposed to bring prior art to the attention of the Patent Office. A free ride off another's opposition to the patent, a share of the patentee's supracompetitive price or, in appropriate cases, reliance upon

271. See generally Titanium Metals Corp. of Am. v. Banner, 778 F.2d 775, 780-82 (Fed. Cir. 1985) (discussing requirements of enablement and anticipation).

272. See 35 U.S.C.A. $\$ 273($ b) $(6)$. 
the first inventor defense ordinarily present superior alternatives to opposing a patent.

Collective action problems are not insoluble. Often the government possesses the ability to change the rules of the game, enhancing the incentives of individuals to engage in desirable conduct. ${ }^{273}$ The patent quality crisis suggests two particular needs. First, applicants must be prodded into performing prior art searches and filing claims that define patentable advances over the prior art. Second, the patent law should encourage prompt third party disclosure of patent-defeating prior art to the Patent Office.

Established federal practice suggests a mechanism for achieving both of these goals. Moiety statutes, ${ }^{274}$ qui tam actions, ${ }^{275}$ the False Claims $\mathrm{Act}^{276}$ and numerous administrative agency programs ${ }^{277}$ have long encouraged individuals to disclose information not within the possession of the government. These schemes typically encourage individuals to assist in law enforcement efforts through the award of a cash prize. ${ }^{278}$

The Internal Revenue Service informant reward mechanism is exemplary. ${ }^{279}$ Since at least 1867 , the IRS has encouraged informants to report violations of the tax laws and awarded a portion of any penalties received as a result of these disclosures. ${ }^{280}$ IRS regulations establish that the bounty will generally not exceed fifteen percent of the taxes recovered, with a cap of two million dollars. ${ }^{281}$ The IRS maintains the anonymity of informants throughout the bounty process. ${ }^{282}$ This bounty system has proven successful over the years, leading to the recovery of several billion dollars of unpaid taxes and the award of millions of dollars

273. DIXIT \& SKEATH, supra note 14, at 370. Some private enterprises do challenge patents prior to being accused of infringement, of course, revealing market-originated resolution of this collective action problem. An industrial actor that believes its gains will outweigh those of his competitors may opt to oppose a patent. The challenger may be less able to develop a substitute product than others in the industry, for example, or may have made greater capital investment concerning the patented invention than others. In such instances the free-rider problem is solved, for the challenger believes the patent is so crucial that the challenge occurs despite potential benefits to others. Concentrated industries also likely enjoy higher reexamination rates. Participants in oligopolic markets should exhibit less diffusion of responsibility and greater willingness to contest an issued patent, an effect that may partially account for heightened opposition rates in Europe.

274. See Doe v. United States, 100 F.3d 1576, 1582 (Fed. Cir. 1996).

275. See 35 U.S.C. $\S 292$ (b) (1994) (false marking statute).

276. See 31 U.S.C. $\$ \$ 3729-3733$.

277. See Matthew Lesko, Uncle Sam Pays Cash to Private Citizens Who Provide Information About Wrongdoings, CHI. TriB., Nov. 1, 1993, at C3.

278. See Marsha J. Ferziger \& Daniel G. Currell, Snitching for Dollars: The Economics and Public Policy of Federal Civil Bounty Programs, 1999 U. ILL. L. REv. 1141, 1142.

279. See I.R.C. \& $7623(2000)$.

280. See An Act to Amend Existing Laws Relating to Internal Revenue, and for Other Purposes, ch. 173, \& 7, 14 Stat. 471,473 (1867).

281. See Treas. Reg. $\$ 301.7623-1$ (c) (as amended in 1998).

282. See Treas. Reg. $\$ 301.7623-1$ (e) (as amended in 1998). 
in bounties. ${ }^{283}$ It also appears quite popular, as the IRS presently receives approximately ten thousand bounty applications each year. ${ }^{284}$

The central proposal of this article is that the patent system should turn to this experience as it considers solutions to its current patent quality crisis. The Patent Office should establish a system of cash prizes, or bounties, to encourage private citizens to provide it with information pertinent to patentability. Members of the public who timely submit prior art that contributes to the rejection of a patent application would be eligible for the bounty. If funded via applicant fines, the proposed bounty program should also encourage inventors to draft patent applications with full cognizance of the most pertinent prior art. This article next reviews the workings of the proposed bounty and considers how the amount of the bounty should be set.

\section{A. The Mechanics of a Patent Bounty}

A regime of patent bounties might operate as follows. The Patent Office would publish applications prior to commencing substantive patent examination efforts. Alongside the application, a search report consisting of the combined results of the applicant's prior art disclosures and the examiner search would also be made available. This publication would trigger a designated time period during which informants might submit pertinent prior art to the Patent Office. Informants would be required to provide a copy of disclosed references, a short explanation of their relevance, and a fee.

Following expiration of the bounty period, substantive patent examination would commence. An examiner would review the search report as well as any references submitted by informants. References originating from informants that are cumulative to the contents of the search report will be set aside. However, if the examiner issues a final rejection of any claim in the application over noncumulative prior art submitted by an informant, then the applicant would be fined and the informant paid. ${ }^{285}$ If the applicant chose to appeal the rejection to the Patent Office Board, or subsequently to the courts, then the award of the bounty should be deferred until the final rejection is upheld.

283. See Frank Green, Telling on Cheats: How to Profit by Putting the IRS on the Tax Fraud's Trail, SAN DIEGo UNION-TRIB., Mar. 29, 1998, at 11.

284. Ferziger \& Currell, supra note 278 , at 1188.

285. The term "final rejection" is a technical one in the patent law. The Patent Act allows an applicant to respond to an initial examiner rejection by amending the claims or through substantive argument. See 35 U.S.C. $\$ 132$ (1994). If the examiner remains unconvinced, then the initial rejection becomes a final rejection. Under this proposal, if the applicant traverses the examiner's rejection without amending the claims to account for an informant reference, then the bounty would not be awarded. In the event of multiple bounty seekers, the prize should go to the first informant to submit a patent-defeating reference. If the examiner relies upon a combination of references submitted by multiple informants, the informants could split the bounty. 
The award of a bounty does not necessarily mean that the applicant is denied the opportunity to obtain a patent. The inventor may file a socalled continuing application and amend his claims in order to distinguish his invention from the cited references. ${ }^{286}$ This proposal contemplates a bounty period only when an application is initially filed, or in those rare cases where so-called new matter is added to the application. ${ }^{287}$

Under this proposal, the Patent Office would retain both the identity of the applicant and the informant in confidence. Anonymity is a feature of many civil bounty schemes and its virtues should apply to the patent system as well. ${ }^{288}$ Anonymously published applications help prevent collusion between potential informants and patentees. Otherwise we could expect that some informants would forward prior art references to the applicant rather than the Patent Office, hoping to obtain an amount larger than the potential bounty. The promise of anonymity would also encourage whistleblowers. A company employee, for example, should be able to submit prior art to the Patent Office even if his employer is the applicant. The governing statute should further render employee covenants not to participate in the patent bounty program unenforceable. ${ }^{289}$

The core virtue of a patent bounty is that it recruits members of the public to act as private patent examiners. With congressional policies increasingly turning the Patent Office into a gutted house, we must stimulate the private sector to place prior art into the system as early as possible. We must also further burden applicants with the expense of locating the best prior art, whether they conduct the search themselves or are forced to pay another to do so.

It is important that awarded bounties be funded directly by an individual patent applicant rather than be appropriated from the Patent Office budget. The prospect of a fine will encourage inventors to file patent applications of the appropriate scope. This framework also avoids nettlesome problems of collusion between informants and applicants. The specter of colluding individuals filing a sequence of bogus applications, followed by prompt informant disclosures of patent-defeating references and Patent Office award of a bounty from its general funds, should be avoided at all costs.

Another merit of the proposed bounty statute is that it essentially includes its own sunset provision. If our current patent quality problems truly are transitional in character, ${ }^{290}$ then the bounty program would wither as the Patent Office expands its prior art libraries and improves its

286. See id. $\S 120$.

287. See id. §132.

288. See Ferziger \& Currell, supra note 278, at 1157.

289. See generally Jodi L. Short, Killing the Messenger: The Use of Nondisclosure Agreements to Silence the Whistleblower, 60 U. PITT. L. REV. 1207 (1999) (arguing against the use of employee nondisclosure agreements to silence whistleblowers).

290. See supra notes 123-24 and accompanying text. 
searching capabilities. A Patent Office already possessed of all the relevant prior art would find any informant submission cumulative and decline to award a bounty.

In order to be eligible for the bounty, informants should be charged a fee sufficient to cover Patent Office administrative expenses and to discourage reference flooding. Informant submissions should also be published promptly in order to minimize duplicative searching by others. A requirement that informants present their materials in electronic format and themselves upload the data to an Internet website appears apt.

The class of potential patent informants should prove to be a diverse one. Competitors of patent applicants will likely be among those newly stimulated to apply for bounties. Other bounty seekers will arise from the industry of patent searchers that currently clusters around the great patent offices of the world. We can also expect that retired patent examiners would be particularly effective informants, but should be concerned that knowledge of the application was gained during the course of Patent Office employment. The governing statute should proscribe bounty awards to former examiners for a set period following that individual's last date of employment at the Patent Office. ${ }^{291}$

Informants might also arise from a newly arisen class of detractors of the patent system. Most of this group consists of technically trained individuals who provide prior art searching services. Their principal method of promoting their services has been to fuel public concern over patent quality. Inspired by the outspoken Gregory Aharonian, this group combines the virtues of a public interest watchdog with the vices of a norm-enforcing community crank. ${ }^{292}$ Patent Office management has noted its displeasure at the often venomous commentary of these individuals and their deleterious effect upon examiner esprit-de-corps. A patent bounty would allow this class to offer positive contributions to the patent system, submitting pertinent prior art to the Patent Office instead of posting it on the Internet alongside cynical remarks.

This bounty proposal is confined to software and business method applications. Problems of patent quality appear to loom the largest in these disciplines. Information economics and the first inventor defense also suggests that we have the most to fear about Patent Office errors here. ${ }^{293}$ Nothing prevents the expansion of this proposal to other sorts of inventions, however. Business method and software applications could serve as a testing ground for this bounty scheme as the Patent Office considers expanding the program into additional fields.

291. See Ferziger \& Currell, supra note 278, at 1147.

292. See generally Jenna Greene, Pundit or Pest?, 158 N.J. L.J. 372 (1999) (describing the efforts of Aharonian to monitor the activities of the patent office).

293. See supra notes $132-45$ and accompanying text. 


\section{B. Determining the Amount of the Bounty}

A crucial feature of any bounty system is the amount of the payment. If bounties are too low, then few informants will participate. If set too high, then a surplus of informants may seek to hit the jackpot. Much like an inefficient patent race, where rent-seeking participants dissipate the value of the patent in their rivalry to obtain it, a generous bounty could promote overinvestment in prior art research. ${ }^{294}$ An overly high bounty might also discourage too many inventors from seeking patent protection. ${ }^{295}$

This article posits no definitive figure as to the optimal amount of the patent bounty. Further empirical research is needed to arrive at this figure. However, we have found pertinent factors that should inform the bounty calculation, however. These elements include current patent acquisition and search fees, the sums associated with other bounty regimes, and behaviors we might influence by appropriately adjusting to the bounty.

The financial liabilities of contemporary patent applicants provide an initial sense of the sums at stake. Patent applicants owe money both to the Patent Office and to their patent attorney. The Patent Office currently charges applicants $\$ 710$ to file an application and $\$ 1240$ to issue an approved patent application. ${ }^{296}$ The Patent Office has also established numerous surcharges and sundry assessments that often exceed these basic charges. ${ }^{297}$ Still, Patent Office fees are usually far less than attorney fees. Most attorneys charge fees "easily total[ing] many thousands of dollars" for the preparation of a simple patent application. ${ }^{298}$ A considerable amount more is required for complex technologies, extended prosecution, or the filing of an appeal to the Patent Office Board. Patent applicants should know they have entered into a costly affair, and the possibility of a bounty award of several thousand dollars appears reasonable.

A second input should be prevailing market rates for a prior art search. Private enterprises frequently employ such searches in order to gauge the validity of an issued patent. Fees for a prior art patent and literature search begin in the neighborhood of $\$ 1000$ but can climb much higher. ${ }^{299}$ Although typical prior art searches are conducted for a set,

294. See ERIC RASMUSEN, GAMES AND INFORMATION 343-45 (2d ed. 1994).

295. See id.

296. See Fees and Payment of Money, 37 C.F.R. $\S 1.16(a), 1.18(a)$ (2000).

297. See id. $\$ \$ 1.160-.20$.

298. Valerie Calloway, In the Process of Controverting Its Constitutionally Given Purpose the U.S. Patent System Discriminates Against Inventors with Limited Financial Means, 11 LAW \& INEQ. 565, 570-71 (1993).

299. See Patent Validity and Invalidity Studies, at http://www.bustpatents.com (last visited Sept. 24, 2000) (on file with the University of Illinois Law Review); see also Invention Patenting Group, at http://www.inventionpatenting.com/legalfees.html (last visited Aug. 21, 2000) (on file with the University of Illinois Law Review). 
certain fee, seekers of the proposed bounty bear additional risks. Not only might another informant be the first to submit particular prior art, the examiner may take a different view of the reference during prosecution. Plainly the bounty must be set at some higher amount in order to account for these risks, for otherwise competent prior art searchers would prefer other work.

Experience with other bounty programs should also prove instructive. As many bounty systems base the amount of the award upon the payoff to the government, ${ }^{300}$ an award structure of little use to the Patent Office, this comparative approach may not initially appear promising. However, a variety of federal agencies, ranging from the National Marine Fisheries Service to the National Highway Traffic Safety Administration, provide for awards of fixed sums. ${ }^{301}$ A review of more discretionary reward schemes should also be of interest. As well, tips to such authorities as the Customs Service and the Drug Enforcement Agency often lead to the seizure of illegal drugs or other contraband that cannot be liquidated. ${ }^{302}$ Both the Secretary of the Treasury and the Attorney General are still entitled to reward informants, however, and these officials are afforded considerable discretion in setting the amount of the informant award. ${ }^{303}$ The policies of these authorities, the reward amounts, and the extent to which any changes in the reward policies have influenced informant behavior would seem particularly helpful information to guide the law of patents.

More theoretical concerns should also inform the practical. The patent bounty proposal surmises that private actors are superior information providers as compared to current Patent Office bibliographic resources. ${ }^{304}$ The patent community should therefore have few qualms about awarding a bounty to a private informant that is equal to or less than the amount spent by the Patent Office on information acquisition. A Patent Office determination of the average amount spent on prior art gathering and review costs for each patent application would seem of particular use in setting the bounty.

There is much to be said for setting the bounty to a sum certain. The Patent Office need not establish a uniform bounty, but potential applicants and informants should know the potential sum at play for a particular application. A settled amount avoids the difficulties of evaluating the worth of disclosed information as well as arbitrary examiner deci-

300. For example, the False Claims Act calls for a reward of $15 \%$ to $30 \%$ of the penalty imposed upon individuals who defrauded the federal government. "A [Securities and Exchange Commission] bounty cannot exceed $10 \%$ of the government take," while at the Internal Revenue Service the typical bounty awarded is in the neighborhood of $15 \%$ of the recovery. Ferziger \& Currell, supra note 278, at 1146 tbl. $1,1152$.

301. See id. at $1143-44$ n.12.

302. See id. at 1156.

303. See 19 U.S.C. $\$ 1619$ (a) (1994); 21 U.S.C. $\$ 886$ (a) (1994).

304. See supra notes $60-98$ and accompanying text. 
sions. A fixed reward also promotes efficient behavior among bounty seekers, who can discount the prospective award based upon individual risk assessments.

Yet it is also tempting to adjust the bounty based upon the qualities of the information provided by the successful informant. The patent law features a notoriously broad definition of prior art. The costs of acquiring information vary considerably among the different categories of eligible information sources. For example, the costs of obtaining a pertinent century-old Romansch language pamphlet available at the public library in Lugano, Switzerland, is much higher than citing a lead story from last year's Science magazine. An accounting for these variable information acquisition costs could be reflected in the patent bounty.

This sort of bounty adjustment could prove a powerful tool for influencing the behavior of applicants and bounty seekers. An argument could be made that the amount of the bounty should be increased when an informant's foreign, obscure reference proves patent-defeating. The better view seems to be that patent quality begins with applicants, however. Providing financial incentives for applicants to perform thorough prior art searches appears the best mechanism for achieving this goal. Under this view, the Patent Office should define a discrete number of publicly available databases, journals, and other common information sources. Informant disclosure of a prior art reference found in one of these sources would increase the amount of the bounty by a fixed amount. This ruling would encourage patent applicants to perform due diligence with respect to designated repositories of prior art or potentially face adverse financial consequences.

The patent system includes a final feature pertinent towards setting the amount of a bounty. The Patent Office presently provides a fifty percent fee discount for so-called small entities: independent inventors, companies with less than 500 employees, and universities. ${ }^{305}$ Given the strength of congressional policies favoring small entities at the Patent Office, halving the amount of the bounty and concomitant fine for small entities appears appropriate as well.

\section{SCRUTINY OF THE BOUNTY}

The proposed patent bounty follows logically from the needs of the modern patent system and longstanding federal administrative practice. Still, adoption of a bounty regime within the patent law could prove a transformative event, fundamentally altering inventor decisions whether to seek patent protection, requiring careful administrative implementation, and creating an entire industry of patent bounty hunters. The dra-

305. See 35 U.S.C. $\S 41(\mathrm{~h})(1994)$. 
matic nature of this proposal prompts several concerns that are worthy of further consideration here.

\section{A. Promoting Trade Secrecy}

The prospect that a bounty system may discourage individuals from seeking patent protection is a paramount concern. Valid sources of prior art are often difficult to discover or even unknowable. ${ }^{306}$ Even diligent and well-intentioned inventors might therefore be required to pay fines that are transferred to informants. Possible consequences of a bounty regime include increasing reliance upon trade secret protection and perhaps even a decreasing rate of innovation. ${ }^{307}$ With patent rights potentially more costly to obtain, prospective inventors may devote resources to activities other than invention.

Although these arguments cannot be entirely discounted, there are several reasons to believe that they should not prove so worrisome as to defeat the patent bounty proposal. First, not every invention is amenable to trade secret protection. ${ }^{308}$ Some inventions are fully disclosed during their operation. Recently issued patents on methods of financing secondary education or training custodial personnel describe inventions of this nature..$^{309}$

The use of many other inventions does not fully expose them but is nonetheless sufficiently revealing to skilled artisans that trade secrecy is defeated. Many Internet-based business concepts, such as Amazon.com's one-click ordering method, fall into this category. ${ }^{310}$ A customer purchasing a book via a single click of her mouse button does not necessarily know how Amazon.com implemented this invention within an Internet environment. Nonetheless, a skilled computer scientist could readily write software to implement one-click ordering upon visiting the Amazon.com website.

For these types of inventions, we should not suspect that the prospect of paying a reasonable finder's fee for pertinent prior art should be overly discouraging to the would-be patent applicant. The inventor would be unable to maintain the invention as a trade secret for very long. Although copyright presents an alternative for inventions with a software implementation, this form of protection is more strongly tied to the wording of the program text and requires derivation from the inventor. ${ }^{311}$

\footnotetext{
306. See supra notes $67-98$ and accompanying text.

307. See Merges, supra note 5, at 599.

308. See Daniel C. Munson, The Patent-Trade Secret Decision: An Industrial Perspective, $78 \mathrm{~J}$. PAT. \& TRADEMARK OFF. SOC'Y 691-93 (1996).

309. See U.S. Patent No. 5,851,117 (issued Dec. 22, 1998); U.S. Patent No. 5,809,484 (issued Sept. $15,1998)$.

310. See supra notes $143-49$ and accompanying text.

311. See Lotus Dev. Corp. v. Borland Int'l, Inc., 49 F.3d 807 (1st Cir. 1995), aff'd by an equally divided Court, 516 U.S. 233 (1996) (suggesting that software may be copyrighted, although concurrence sees most software as not copyrightable).
} 
In sum, many inventors who seek intellectual property protection have no alternative but to seek patent protection.

Second, the First Inventor Defense Act of 1999 indicates a favorable congressional posture towards trade secret proprietors in the area of business methods. Legislative reports accompanying the First Inventor Defense Act indicate that Congress intended this statute to solve transitional problems accompanying the sudden patentability of business methods. ${ }^{312}$ Yet the First Inventor Defense Act is prospective in character, available in any litigation commenced after November 29, 1999. ${ }^{313}$

That Congress did not limit the first inventor defense to trade secrets developed prior to the State Street Bank decision suggests a special solicitude for business methods held as trade secrets. Secure that they can employ a trade secret unhindered by a subsequent patentee, business method practitioners stand on steadier footing than trade secret holders within other disciplines. ${ }^{314}$ A message from the First Inventor Defense Act is that we have less to fear about trade secrecy in the area of business methods. Our long history of advances in the area of business methods, despite the uncertainty of patent protection, reinforces this conclusion. ${ }^{315}$

Finally, desperate times call for desperate measures. The increasing erosion of our patent system calls for decisive corrective action. In keeping with the congressional mandate for a self-supporting Patent Office, the users of our patent system must bear the burdens of improving it. While assessing whether fear of financing a bounty would drive many inventors into hiding, we should recognize that patent acquisition is already an expensive business. If the amount of the bounty is set to an appropriate level, ${ }^{316}$ then we are unlikely to observe a decline in patent applicants.

\section{B. Signaling}

Anonymity is a core feature of the proposed bounty patent. Without such a guarantee, informants may fear reprisals from enterprises that have been forced to pay them a bounty. Potential informants would also be able to collude with the applicant, burying rather than disclosing patent-defeating prior art. ${ }^{317}$

312. See H.R. REP. No. 106-287, pt. 1, at 46 (1999).

313. See Richard Neifeld, Analysis of the New Patent Laws Enacted November 29, 1999, 82 J. PAT. \& TRADEMARK OFF. SOC'Y 181, 195 (2000).

314. See supra notes 257-64 and accompanying text.

315. See Leo J. Raskind, The State Street Bank Decision: The Bad Business of Unlimited Patent Protection for Methods of Doing Business, 10 Fordham INTEll. Prop. MEdia \& ENT. L.J. 61, 78 (1999) ("In the absence of data showing a need to spur innovation in business methods, it is equally plausible that the spur of competition and the long tradition of competition by emulation have been sufficient to provide an adequate level of innovation in methods of doing business.").

316. See supra notes $280-91$ and accompanying text.

317. See supra note 242 and accompanying text. 
Experience with other bounty programs suggests that the maintenance of informant identities in confidence is an achievable objective. ${ }^{318}$ Preservation of the applicant's anonymity presents a much more legitimate concern, however. The number of actors on the inventive forefront is quite small in many disciplines. Applicants might also market products that embody the claimed invention or simply convene press conferences in order to announce their advances.

Experience also teaches us that enterprises have engaged in ingenious signaling techniques when it suits their interest. One noteworthy example involved FCC airwave spectrum auctions that employed simultaneous bidding. Certain bidders allegedly signaled their intentions to pursue licenses in certain locations by employing their telephone area codes or other individual indicia within their bids. ${ }^{319}$ As compared to a single dollar amount, patent applications provide a robust medium that applicants could manipulate to reveal their own identities. Inventors enjoy a great deal of discretion in drafting these often lengthy texts. Even well-intentioned applicants may have developed a distinct style that betrays their identities, despite the rigid genre.

Although these concerns cannot be eliminated, there is much reason to believe that signaling would not defeat the goals of the proposed patent bounty. In the realm of software and Internet-based business concepts, considerable public commentary suggests the existence of an outspoken, technically astute community of free thinkers. These individuals appear much more likely to beat down the doors of Crystal City with prior art references than collaborate with those who would appropriate a piece of the Internet. More generally, the Patent Office includes an Office of Enrollment and Discipline that is accountable for policing applicant abuses.

\section{Agency Discretion and Judicial Review}

The proposed bounty may raise concerns over Patent Office administration of the bounty regime and the possibility of judicial oversight. A Patent Office Solicitor's Office beleaguered by satellite litigation brought by disgruntled bounty seekers or fined applicants is not a pleasant prospect. In a bounty regime, virtually every patent application would seem pregnant with the possibility for peripheral disputes.

Standing bounty provisions again provide the answer. Among others, the Securities and Exchange Commission bounty statute renders reward decisions "final and not subject to judicial review." 320 The case law similarly establishes that payments to IRS informants lies wholly within

318. Ferziger \& Currell, supra note 278, at 1175.

319. DiXIT \& SKEATH, supra note 14, at 517.

320. 15 U.S.C. \& $78 \mathrm{u}-1$ (e) (1994). 
the discretion of the Commissioner ${ }^{321}$ Without apology, the proposed patent bounty statute should read similarly. The complexity of the examination task, the vagaries of the interpretation of patent applications and prior art references, and the volume of applications suggest that agency discretion is paramount in this context. Standardized procedures, fixed bounty amounts and the ultimate safeguard of political accountability should check arbitrary Patent Office decisions in this context.

\section{Ethics and Efficiencies of Organizational Behavior}

Principles of the patent community provide a final source of objection to the proposed patent bounty. Opportunistic snitches have been maligned long before the days of Linda Tripp. ${ }^{322}$ Civil bounty schemes too have also been called into question on moral grounds. For example, Senator Harry Reid of Nevada recently labeled the IRS informant program "Rewards for Rats" and called for its repeal. ${ }^{323}$ Inspired as it is by existing civil bounty regimes, the proposed patent bounty might prompt similar concerns.

In most circumstances the proposed patent bounty statute steers clear of these moral hazards. A patent informant does not accuse others of wrongdoing, but instead discloses pertinent information of a technical nature. The anonymity of all participants in the patent bounty system should further encourage a neutral environment for prior art research and disclosure. Patent bounty seekers would be less stool pigeons than research assistants, bibliographers, and practical historians who could contribute meaningfully to our patent examination regime.

The possibility of a patent bounty may give rise to additional concerns with the employment relationship, however. Employers might be wary of the prospect of employees secretly opposing their patent acquisition efforts. They may wish to erect Chinese walls, develop nondisclosure practices, and restrict access to technical information that could be used against them. Not only may these reconfigurations of work patterns prove costly and inefficient, they may diminish synergistic interactions between individuals that often leads to innovation. ${ }^{324}$

Although this concern cannot be wholly discounted, it must be assessed against a legal and commercial background where firms already possess considerable incentives to conceal valuable information. Enterprises presently must implement reasonable secrecy measures for information to achieve protection as a trade secret. ${ }^{325}$ Many innovative companies already insist that employees undertake covenants not to

321. See I.R.C. $\$ 7623$ (West Supp. 1999)

322. See Ferziger \& Currell, supra note 278, at 1141.

323. See 144 CONG. REC. S4379, S4398 (daily ed. May 6, 1998) (statement of Sen. Reid).

324. See Rockwell Graphic Sys. v. DEV Indus., 925 F.2d 174, 180 (7th Cir. 1991).

325. See RESTATEMENT (THIRD) OF UNFaIR COMPETITION $\$ 39(f)$ (1995). 
compete. ${ }^{326}$ Even where an employer has no intention of seeking relief under the intellectual property or contract laws, secrecy measures are conventionally employed as a matter of common sense and self-help. Although a patent bounty program might reinforce these norms, its impact would surely be felt only on the margins.

A final concern is that an unscrupulous employee might encourage his employer to file a patent application, all the while withholding information that would defeat it. Once the Patent Office publishes the employer's application, then the employee or his agent might disclose this information to the Patent Office and request a bounty. Although any sort of public reward regime will undoubtedly present corrupt employees with an opportunity to seek graft, Patent Office regulations should go a long way towards policing such conduct. These regulations impose a duty of candor upon inventors, their patent attorneys, and every other person substantially involved in the preparation and prosecution of an application. ${ }^{327}$ Upon submitting prior art believed pertinent to a particular application, informants should be required to certify both that they are not under an obligation of disclosure with respect to that application, and that they have not derived the disclosed information from another who is under such a duty. The reminder that punishment accompanies the submission of a false oath, along with selective scrutiny and enforcement by the Office of Enrollment and Discipline, ought to curb this potential abuse.

\section{CONCLUSION}

The assertive vision of the patent system championed by such decisions as Diamond v. Diehr and State Street Bank should have been met with more vigorous resistance. The sheer number of issued patents claiming such concepts as Internet-based business models, ${ }^{328}$ financial methods, ${ }^{329}$ and instruction techniques ${ }^{330}$ suggests that the time for debate over patent eligibility is past, however. The law is now well established that inventors who properly prepare applications face few barriers to patenting beyond those associated with the prior art. Having shepherded the patent law to these breathtaking heights, we are left to address the apparent difficulties the Patent Office has encountered in examining applications from unfamiliar disciplines. Lean times call for bold solutions to resolve this fundamental crisis of integrity within the patent system.

This article calls upon the patent community to recognize that problems of collective action and collusion have contributed to our current

326. See Ronald J. Gilson, The Legal Infrastructure of High Technology Industrial Districts: Silicon Valley, Route 128, and Covenants Not to Compete, 74 N.Y.U. L. REV. 575, 603 (1999).

327. See 37 C.F.R. \& 1.56(a) (1999).

328. See U.S. Patent No. 5,797,127 (issued Aug. 18, 1998).

329. See U.S. Patent No. 5,809,484 (issued Sept. 15, 1998).

330. See U.S. Patent No. 5,851,117 (issued Dec. 22, 1998). 
patent quality problems. The newly minted first inventor defense can only accelerate the decline in the legitimacy of issued business method patents. The proposed patent bounty would counter these trends in ways no opposition can, effectively aligning the incentives of both inventors and third parties with the public interest. Employing private citizens as partners in patent examination offers a fiscally realizable solution for restoring order to our patent system and ultimately lowering its social costs. 